\title{
Informing the public health response to COVID-19 (and lessons learnt for future pandemics): a systematic review of risk factors for disease, severity, and mortality.
}

\section{Mary Flook}

University of Edinburgh

Charlotte Jackson

University College London

Eleftheria Vasileiou

University of Edinburgh

Colin R. Simpson

University of Edinburgh

Marisa D. Muckian

University of Edinburgh

Utkarsh Agrawal

University of St. Andrews

Colin McCowan

University of St. Andrews

Yumeng Jia

Freelance consultant

Josie L.K. Murray

National Health Service

Lewis D. Ritchie

University of Aberdeen

Chris Robertson

University of Strathclyde

Sarah J. Stock

University of Edinburgh

Xin Wang

University of Edinburgh

Mark E. J. Woolhouse

University of Edinburgh

Aziz Sheikh

University of Edinburgh 


\section{Helen R. Stagg ( $\sim$ helen.stagg@ed.ac.uk)}

University of Edinburgh

Keywords: coronavirus, COVID-19, systematic review, review, risk factors, morbidity, mortality,

Posted Date: June 19th, 2020

DOI: https://doi.org/10.21203/rs.3.rs-36375/v1

License: (c) (1) This work is licensed under a Creative Commons Attribution 4.0 International License. Read Full License 
Informing the public health response to COVID-19 (and lessons learnt for

future pandemics): a systematic review of risk factors for disease, severity, and mortality

M. Flook ${ }^{1}$, C. Jackson ${ }^{2}$, E. Vasileiou ${ }^{1}$, C.R. Simpson ${ }^{1,3}$, M.D. Muckian ${ }^{1}$, U. Agrawal ${ }^{4,}{ }^{,}$, C. McCowan $^{4,{ }^{*}}$, Y. Jia ${ }^{5,{ }^{*}}$, J.L.K. Murray ${ }^{6,7,{ }^{*}, \text { L.D. Ritchie }}{ }^{8,{ }^{*}}$, C. Robertson ${ }^{9,{ }^{*}}$, S.J. Stock ${ }^{1, *}$, X. Wang $^{1,{ }^{*}}$, M.E.J. Woolhouse ${ }^{1,10,{ }^{*}}$, A. Sheikh ${ }^{1}$, H.R. Stagg ${ }^{1}$

${ }^{1}$ Usher Institute, University of Edinburgh, UK

${ }^{2}$ Medical Research Council Clinical Trials Unit, University College London, UK

${ }^{3}$ Wellington School of Health, Faculty of Health, Victoria University of Wellington, Wellington, New Zealand

${ }^{4}$ School of Medicine, University of St. Andrews, UK

${ }^{5}$ Freelance consultant, People's Republic of China

${ }^{6}$ National Health Service Fife, UK

${ }^{7}$ Public Health Scotland, UK

${ }^{8}$ School of Medicine and Dentistry, University of Aberdeen, UK

${ }^{9}$ Department of Mathematics and Statistics, University of Strathclyde, UK

${ }^{10}$ School of Biological Sciences, University of Edinburgh, UK

*These authors contributed equally and are presented alphabetically by surname

Corresponding author: Dr. Helen R. Stagg, Usher Institute, University of Edinburgh, 30 West Richmond Street, Edinburgh, EH8 9DX, UK; helen.stagg@ed.ac.uk; +441316511447 


\begin{abstract}
Background

Severe Acute Respiratory Syndrome coronavirus-2 (SARS-CoV-2) has challenged public health agencies globally. In order to effectively target government responses, it is critical to identify the individuals most at risk of coronavirus disease-19 (COVID-19), developing severe clinical signs, and mortality. We undertook a systematic review of the literature, to present the current status of scientific knowledge in these areas and describe the need for unified global approaches, moving forwards, as well as lessons learnt for future pandemics.
\end{abstract}

\title{
Methods
}

Medline, Embase and Global Health were searched to the end of April 2020, as well as the Web of Science. Search terms were specific to the SARS-CoV-2 virus and COVID-19. Comparative studies of risk factors from any setting, population group and in any language were included. Titles, abstracts and full texts were screened by two reviewers and extracted in duplicate into a standardised form. Data were extracted on risk factors for COVID-19 disease, severe disease, or death and were narratively and descriptively synthesised.

\section{Results}

1,238 papers were identified post-deduplication. 33 met our inclusion criteria, of which 26 were from China. Six assessed the risk of contracting the disease, 20 the risk of having severe disease and ten the risk of dying. Age, gender and co-morbidities were commonly assessed as risk factors. The weight of evidence showed increasing age to be associated with severe disease and mortality, and general comorbidities with mortality. Only seven studies presented multivariable analyses and power was generally limited. A wide range of definitions were used for disease severity. 


\section{Conclusions}

The volume of literature generated in the short time since the appearance of SARS-CoV-2 has been considerable. Many studies have sought to document the risk factors for COVID19 disease, disease severity and mortality; age was the only risk factor based on robust studies and with a consistent body of evidence. Mechanistic studies are required to understand why age is such an important risk factor. At the start of pandemics, large, standardised, studies that use multivariable analyses are urgently needed so that the populations most at risk can be rapidly protected.

This review was registered on PROSPERO as CRD42020177714.

Key words: coronavirus, COVID-19, systematic review, review, risk factors, morbidity, mortality 


\section{Introduction}

The world is currently experiencing a pandemic of coronavirus disease (COVID-19) caused by the Severe Acute Respiratory Syndrome coronavirus-2 (SARS-CoV-2).(1) The risk of morbidity and mortality from the virus is strongly stratified, with poor clinical outcomes considered more likely in certain vulnerable groups. For example, studies from different countries have established that older age groups are at increased risk of death. $(2,3)$

The ability to identity the population groups most at risk from the virus has manifold public health purposes. Using such data, stratified vaccination policies for governmental delivery can be designed, similar to those for influenza.(4) Prioritised access to healthcare facilities can be determined, i.e. early identification of the individuals most likely to progress to severe disease and thus in need of intensive care and ventilation. Official advice can be issued to vulnerable groups to let them know that they are more at risk from SARS-CoV-2 virus, to promote behaviour modification. $(5,6)$ Such population groups can also be the target of more formalised 'segment and shield' approaches, whilst relaxing restrictions for the rest of the population.(7) Potential public health policies along this route have been critiqued, however, on an inclusivity basis, particularly due to the unintended harmful consequences to already marginalised groups.(8)

In the UK, vulnerable people have been stratified into two tiers (Table 1); those at risk of severe illness, who were advised to be particularly stringent with social distancing measures, and those within that group at further risk - described as 'shielded' individuals - who were advised to self-isolate and were provided with additional advice.(9-12) The former categorisation was based on the groups targeted for National Health Service programmes on influenza vaccination and the latter on clinical consensus. These strata were deliberately broad, to maximise the number of individuals protected. As the evidence evolves - e.g. regarding the involvement of the cardiovascular system(13) - there is the opportunity for the 
categorisation of risk of COVID-19 and serious outcomes from COVID-19 to become more evidence-based.

During epidemics and pandemics of emerging infectious diseases, it is critical to rapidly and accurately identify the populations most at risk. In the case of COVID-19, we undertook a systematic review and quality assessment of the rapidly-evolving global literature in this area, looking at three key outcomes: COVID-19 disease, disease severity, and mortality from the condition. Any potential risk factors, populations, and study designs were included. Arising from our findings, we highlight key knowledge gaps in the current literature and the need for unified global approaches moving forwards, particularly for the next pandemic.

\section{Materials and methods}

\section{Literature search}

We systematically searched Medline, Embase, and Global Health (all via the Ovid platform), in addition to the Web of Science, for published literature between $1^{\text {st }}$ November 2019 and $26^{\text {th }}$ March 2020; then subsequently updated this search for a later period to $29^{\text {th }}$ April. In order to avoid missing publications on risk factors, only terms specific to the virus and the disease were used, which were combined with 'or':

- 'coronavirus'

- 'covid-19'

- 'severe acute respiratory syndrome coronavirus 2'

- '2019-nCoV-2'

- 'SARS-CoV-2'

- ' 'acute respiratory syndrome'

No limits or filters were applied to the search. The same search terms were used across all databases. 
Reference lists of included papers and review articles were also searched, as was the grey literature of public health reports for the 26 countries with the highest numbers of reported patients with COVID-19 at the end of April 2020.

\section{Eligibility criteria and study selection}

The following inclusion and exclusion criteria were applied to the search results.

Inclusion criteria:

- Studies had to provide comparative data on risk factors of any kind for disease (versus no disease), severe disease (versus milder disease) or mortality (versus survival),

- COVID-19 patients had confirmed infection with SARS-CoV-2 after polymerase chain reaction (PCR) testing. PCR testing was the gold standard test for active disease at the start of the pandemic,(14) only later followed by serological tests,

- Any study design,

- Any population group,

- Any language of publication.

Exclusion criteria:

- No comparator group included in the study,

- Publication concerned other viruses and diseases,

- Work conducted in animals or in vitro,

- Study population was less than 20 individuals.

Two reviewers independently screened all titles, abstracts and full texts for both literature searches. Discrepancies were resolved by consensus. Studies published in languages other 
than English were screened by at least one additional reviewer, with further quality control by another member of the reviewing team.

\section{Data extraction}

Three reviewers independently double-extracted the studies into a pre-designed spreadsheet that collected:

- First author,

- Paper title,

- Journal,

- Type of study,

- Country,

- Study population,

- Overall number in study,

- Number with PCR confirmed SARS-CoV-2,

- Median age of participants/age range,

- Sex ratio,

- Analytical method used,

- Factors adjusted for during the analysis,

- Whether disease, disease severity, or death (or a combination of these) was the outcome of interest,

- The definition of disease severity used, if applicable,

- The risk factors analysed and the direction of effect.

Results were compared and discrepancies resolved by discussion. Data from studies published in languages other than English were extracted by two additional reviewers, with further quality control by another member of the reviewing team. 


\section{Quality assessment}

Two reviewers independently assessed the quality of included studies. Studies published in languages other than English were quality assessed by two additional reviewers, with further quality control by another member of the reviewing team. Assessments were undertaken from the perspective of the objectives of this review, which were not necessarily identical to the objectives of the underlying studies. The quality of included studies was assessed using a checklist adapted from Downs and Black,(15) as per the guidance issued by Deeks et al.(16) When assessing the power of studies, the minimum sample size required to detect a relative increase in risk of $10 \%$ from a statistically conservative baseline of $50 \%$ among the unexposed was calculated at different powers using the Kelsey method within Epi Info. This $10 \%$ value was based on governmental discussions taking place in the UK at the time the review took place. An alpha of $5 \%$ was set as the standard. Pragmatically, we assumed only two strata and a ratio of 1:1 between exposure strata. Different thresholds were used for case-control studies and for cohort or cross-sectional studies. These criteria were scored from 0 ( $<70 \%$ power) to 5 ( $>99 \%$ power). We considered results sufficient adjusted for confounding if they adjusted for at least the minimal variable set of age, sex, ethnicity and any measure of comorbidities. For ethnically homogenous populations, the need for adjustment for ethnicity was discounted. If two analyses were presented within a single paper with different quality scores, the most conservative score was retained. Studies were not excluded on the basis of the quality assessment.

\section{Analysis and synthesis}

Studies were grouped on the basis of the outcome examined (disease, disease severity, mortality) and then the risk factors examined. Results were classified on the basis of whether they presented evidence as to the exposure under study being a risk factor, taking into account the number of individuals exposed. Where studies focussed on a single risk factor of interest with adjustment for confounding, we extracted all data on potential risks in order to maximise the value of our dataset (whilst accepting that such mutually adjusted estimates for 
covariates may remain confounded even if that for the primary exposure does not).(17) As there was substantial heterogeneity in study design, reporting, and the risk factors examined, we present a detailed descriptive summary and narrative synthesis of our findings, rather than a meta-analysis.

\section{Registration and reporting}

This review was registered on PROSPERO as CRD42020177714 and is reported according to the PRISMA guidelines.

\section{Results}

2,868 hits were obtained by the searches across the two dates (Figure 1). After deduplication across the different databases, this was reduced to 1,238. 30 studies were included at the extraction stage; the main reasons for exclusion were small numbers of participants and studies not having a comparator population. From the grey literature an additional report was included and two studies were identified from reference lists.

Included studies are presented in Table 2. 29 of the 33 studies were conducted in China, with one each from France, Italy, Singapore and a combined study from England, Wales and Northern Ireland. Six were studies with COVID-19 disease as the outcome, 20 of disease severity and ten of mortality. One additional study looked at a combined outcome of disease severity and mortality.

\section{Quality assessment}

Included studies were generally too small to detect a $10 \%$ increase in risk of disease, disease severity, or mortality (Table 3). One study among the 33 was assessed to have $95 \%$ power and two others 99\%; all were large, national, investigations. As 26 studies were purely descriptive or presented univariable analysis only, there was no adjustment for confounding. 
Remaining studies with a regression component did not adjust for our minimal confounder set. Only nine studies provided estimates of the random variability of effect estimates. The majority of studies ascertained exposure information from clinical records, which would have collected data prospectively and thus with limited recall bias. Blinding of outcome and exposure recording by investigators was not documented. In the case of certain disease severity outcomes, such as admittance to intensive care units (ICU), variability in thresholds for reaching these outcomes is likely to exist between settings and clinicians

\section{Risk factors for disease}

Six studies compared the likelihood of having COVID-19 to other infectious conditions (Table 4). Of note, as testing strategies were largely focussed on hospitalised individuals i.e. those displaying noticeable symptoms, studies were of the likelihood of COVID-19 disease, rather than more broadly of SARS-CoV-2 infection (and particularly of severe disease, although patients with mild and symptomatic infection were also reported to be hospitalised in some studies for the purposes of isolation or observation). Age and sex were key foci as potential risk factors, comparing patients with COVID-19 to either: a) SARS-CoV or Middle Eastern Respiratory Syndrome (MERS), or b) other forms of pneumonia. Generally, sex ratios were skewed such that men were over-represented among those with disease. In England, Northern Ireland, and Wales, Asian and Black individuals were found to be at increased risk of COVID-19 in descriptive analyses, with $15.4 \%$ and $10.7 \%$ of patients falling into these groupings, respectively, versus $5.8 \%$ and $2.8 \%$ of individuals with other viral pneumonia.(29) Higher body mass index (BMI) was also suggested to be a risk factor with two descriptive analyses, for example in the Intensive Care National Audit and Research Centre (ICNARC) report $31.2 \%$ of COVID-19 patients had a BMI of $30-<40$, versus $23.5 \%$ of people with other viral pneumonia. $(29,36)$ Given the large, national, scope of the ICNARC dataset, results from it are particularly likely to be reliable. 


\section{Risk factors for severe disease}

Among the 20 studies of risk factors for severe versus milder disease and one of a mixed outcome (severe disease and death), a wide array of definitions of severity were used, such as ICU admission, the need for mechanical ventilation, and various measures of respiration and oxygenation (Table 2). Many risk factors were examined (Table 5). As well as potential demographic risks (age, sex, ethnicity), behavioural traits (smoking) and broad clinical factors (BMI, infectious diseases) were analysed. Large numbers of papers sought to explore the implications of different comorbidities on the risk of severe COVID-19, particularly respiratory and cardiovascular conditions.

The least equivocal evidence was presented for age as a risk factor, including four studies where it was an independent risk in a multivariable regression model. $(18,19,30,35)$ The clearest analysis to present age data (i.e. which used different comparison groups) was a univariable regression model where individuals 65 years and over had 3.26 times the hazard rate of ARDS than those under 65.(43) Eight studies suggested that diabetes could be a risk factor, $(18,30,35,38,40,42,43,49)$ six hypertension, $(30,35,40,42,43,49)$ and four the presence of unspecified comorbidities $)(38,40,47,49)$, but the balance of evidence was generally inconclusive. Many other factors were examined by one study, often with small numbers of individuals with the condition. None of the included studies for disease severity were assessed to have been powered to detect a $10 \%$ increase in effect size.

\section{Risk factors for mortality}

Ten studies examined risk factors for mortality, often by nesting case-control studies within prospective or retrospective cohorts (Table 6). Among these studies, many included statistical testing, but none presented an adjusted regression model for the risk factors considered.

Eight studies examined age and all provided evidence for it being a risk factor for 
mortality, $(20,24,26,34,43-46)$ although none adjusted for other factors, such as comorbidities. Age groups from 50 upwards were considered particularly at risk. In the single regression analysis, the hazard rate for death in those 65 years or over was estimated to be six times that of individuals under 65.(43) The evidence was similarly consistent for general comorbidities (albeit all the studies were descriptive); among individuals who died, comorbidities were 1.5 to 2.8 times more common than among those who survived.(20, 34, $45,46,50)$ Evidence was more equivocal, but still in favour, of hypertension, $(3,20,24,26$, $46,50)$ cardiovascular disease, $(20,24,34,44,46,50)$ diabetes, $(20,24,44-46,50)$ and chronic respiratory/lung diseases being risk factors (references presented for studies in support only).(20, 44, 50) Of these studies, data from two well-powered, national-level studies from China supported cardiovascular disease and diabetes as risk factors for mortality from COVID-19.(24, 44)

\section{Discussion}

In this systematic review of risk factors for COVID-19 disease, disease severity and mortality, we document 33 comparative studies examining sociodemographic, behavioural and clinical exposures. Age and sex were very commonly examined; a wide array of comorbidities have also been considered.

Within the synthesised evidence, risk factors for mortality were the clearest, plausibly partly because this outcome is easy to define. Increasing age (different studies presented different thresholds, but being over 50 years of age was common) was an uncontested risk factor. Five studies also presented evidence for the presence of any comorbidities being a risk factor, $(20,34,45,46,50)$ with none demonstrating evidence against. Given the increasing prevalence of comorbidities with age, the lack of adjustment for confounding in these studies likely over-emphasises the effect size of each risk factor. We note that work subsequent to 
our literature search documents an independent effect of age on COVID-19 mortality from overall comorbidities, as measured by the Charlson Comorbidity Index Score, but not viceversa.(51) Another study published outside of the time range of our search found both age and an array of comorbidities, each analysed separately (chronic cardiac disease, chronic pulmonary disease, chronic kidney disease, chronic neurological disease, dementia, malignancy, moderate/severe liver disease; and obesity), to be independent risk factors (as well as sex).(52)

Risk factors for severe disease were more complex to synthesise, likely due to the mixed array of outcome measures that can also be prone to observer bias. The impact of age was very commonly assessed, generally showing evidence in favour of this being a risk factor (with a similar age spectrum to the mortality data). Ethnicity was studied in two publications, $(25,29)$ with mixed results. We note that such findings are likely to be highly context-specific, given that ethnicity acts as a proxy for a series of sociodemographic factors that are highly relevant to the spread of an infectious condition (as well as, perhaps, some biological traits).

Studies of risk factors for COVID-19 disease have been complicated by testing strategies globally, which have largely been concentrated on severe disease. As our knowledge of the full symptom spectrum of the disease moves forward, it will be possible to have a broader case definition that does not solely focus on viral testing, and thus the ability for more generalised complementary studies. Additionally, serological surveys assessing the history of infection with SARS-CoV-2 in different population groups will allow the identification of risk factors for infection, whether symptomatic or not. Both ethnicity (Black and Asian individuals at higher risk; from a single study in England, Northern Ireland and Wales)(29) and higher BMI were found to be associated with disease severity within the included literature,(29, 36) again from descriptive studies only. While these studies were not eligible for our review, we note a series of reports from non-comparative studies documenting the potential influence of 
ethnicity on the likelihood of getting COVID-19 e.g. the work of Price-Haywood from the US.(51) Male sex was reasonably consistently shown to be a risk factor for presence of COVID-19 but not with severity of disease or mortality. $(23,29,39)$ As with ethnicity, socioeconomic and behavioural factors make this association likely to vary between settings.

In considering the role of comorbidities in COVID-19, it is important to consider the underlying pathology of the virus. Respiratory coronaviruses associated with the common cold in immunocompetent people generally affect only cells in the upper respiratory tract (URT), whereas the previously discovered highly pathogenic coronaviruses SARS-CoV and MERS-CoV affect cells in the URT and lower respiratory tract (LRT). SARS-CoV-2 has been shown to do the same,(53) and one of the host cell receptors it targets is AngiotensinConverting Enzyme 2 (ACE2), with a second major receptor being Transmembrane Serine Protease 2 (TMPRSS2).(54) SARS-CoV-2 can infect all the major cell types in the respiratory tract - type I and type II pneumocytes, alveolar macrophages and endothelial cells. $(55,56)$ This infection leads to cell death, with significant leaking of fluid into the alveolar spaces (pulmonary oedema), which compromises gas exchange,(57) eventually leading to ARDS. The inflammatory response adds aggregation of repair proteins such as fibrin, which can lead to creation of hyaline membranes which further reduces the surface available for gas exchange.(57) Subsequently, inflammatory cells are activated, recruited by release or exposure of cytokines such as the interleukins (IL) $1 \beta$ and 6 , monocyte chemoattractant protein-1,(55) and proteins of the extracellular matrix, as well as upregulation of the complement system. Inflammatory cells release cytokines which have systemic effects, eventually leading to disseminated intravascular coagulation (DIC), hypotensive shock and metabolic disturbances if not checked.(57)

This pathogenesis therefore offers several points where co-morbidities may exacerbate the process. The target receptor TMPRSS2 is modulated in response to air pollution and in autoimmune conditions such as asthma,(54) which may affect the number of receptors 
available for SARS-CoV-2 to target, and ACE2 is involved in the renin-angiotensin system (RAS) which controls blood pressure. Viral interference causes dysfunction, which leads to a pro-inflammatory state and increased vascular permeability in response to changes in vascular contraction and sodium homeostasis - exacerbating the effect from the physical damage to the affected cells. Conditions causing hypertension - both primary and secondary to renal disease, endocrine dysfunctions such as hypothyroidism, cardiovascular dysfunction such as arteriosclerosis, or neurological dysfunctions such as acute stress - also affect the RAS,(57) meaning that these conditions might be expected to exacerbate pathology caused by SARS-CoV-2. Any condition creating a pro-inflammatory state, such as type II diabetes or pre-existing infection, or involving autoimmunity, such as type I diabetes, might also be expected to contribute to increased pathology. There is also the direct effect of cell damage - if the target tissues are already damaged this reduces 'spare' capacity and therefore the leeway for adaptation to allow the host to continue to maintain homeostasis whilst still being able to eliminate the pathogen and repair the damage. The need for inflammatory cells to clear the infection is also a potential area of interface with comorbidities e.g. conditions such as unsuppressed HIV infection or congenital deficiencies, or the administration of immunosuppressant drugs.

The effect of ageing was particularly strong within our review, both in terms of the magnitude of effect estimates and the number of studies presenting evidence. As well as the above impact of comorbidities, we note that the host's age may influence pathogenesis, both in terms of the likelihood of having various comorbidities, and also due to its effect on the immune system. Indeed, the immune system becomes less effective over time (immunosenescence), which affects the quality and number of immune system cells generated.(58) Given the scale of the impact of age documented within this review, it seems unlikely that its effect can be explained by a single or a small number of comorbidities which are yet to be detected. This opens up the need to explore biological markers, for example ACE2,(59) and markers of immunosenescence. 
The strengths of our review include its systematic approach and broad use of search terms to avoid missing studies. We additionally present a quality assessment to aid the interpretation of the strength of the evidence. In some instances, included publications may have focussed on one specific outcome, whereas our quality assessment took the perspective of the outcomes extracted for this review. We were unable to detect instances where two publications used the same patient populations for their analyses, potentially over-emphasising certain findings. Given the global nature of the pandemic, our review includes studies from around the world, albeit with a large preponderance from China, including studies conducted early after the emergence of SARS-CoV-2 when the at-risk population was predominantly those who had contact with Huanan seafood market and their contacts, and not necessarily representative of the general population. We note a particular lack of studies from the African continent and the Americas, which may have implications for generalisability. Given the rapidly evolving literature on COVID-19, we also note our exclusion of studies published after April 2020, and our exclusion of preprints (which was undertaken to ensure that all included studies had undergone an external quality assessment prior to inclusion).

Across the included publications, variability in study design, exposure and outcome measurement, and analyses made exact syntheses of effect sizes across different risk factors very difficult. Measures of disease severity varied, e.g. admission to ICUs or clinical parameters such as percentage oxygen saturation of the blood. Even measures such as admission to ICU can be subjective and may be time-, clinician-, and health systemsdependent. If severity is recorded at admission, risk factors may reflect issues associated with delayed access to healthcare, which may differ between settings and healthcare systems. It is also important to note that, in some studies of disease severity, mild disease included both people who were hospitalised with symptoms and asymptomatic individuals identified through contact tracing. Generally, analyses were descriptive or univariable and 
thus did not control for confounding. As documented above, this may be particularly problematic when it comes to separating the impact of age and the presence of comorbidities, as well as for identifying which comorbidities truly increase risk, given that many patients may have multi-morbidity.

The implications of our findings are two-fold for COVID-19, firstly for current public health practice and secondly for the design of future studies. We flag a number of factors of interest that should be considered by governments and public health agencies when designing shielding strategies and the targeting of future vaccines, as well as in mathematical modelling projecting the likely impact of the pandemic over time. We note, however, the need for sensitive handling of population groups deemed to be at higher risk, and how such labelling does not devolve responsibility from public bodies to these individuals for their own welfare.(8) Some public health agencies are now including reporting of potential risk factors in their routine outputs, including ICNARC (included in this review)(29) and the newer European Centre for Disease Prevention and Control reports, which were released after this review was conducted.(60)

Our review demonstrates both the volume of literature that can be published within only a few months since the appearance of an emerging infectious disease, and the need for coordinated approaches to such pathogens. Global efforts using national datasets are hugely valuable in systematically determining the aetiology of a disease, particularly to detect smaller effect sizes. Determination of the exact threshold of important risk depends on public perceptions of the disease,(61) as well as policy needs. Data collection should be standardised where possible, e.g. by using consistent definitions of outcomes and the treatment of exposures (for example for hypertension, given that blood pressure is continuous). (For COVID-19 we note both the valuable World Health Organization interim guidelines on its management in providing consistent approaches for testing and the definition of ARDS,(14) and that platforms such as the International Severe Acute 
Respiratory and Emerging Infections Consortium (ISARIC) have aimed to facilitate such standardisation.(62)) The choice of comparison groups should also merit careful consideration; comparison to other forms of the same condition (e.g. SARS and MERS for COVID-19), although interesting, provide little information about risk groups to be currently acted upon. Where key potential risk factors of interest, such as deprivation, are linked to both the disease of interest and the comparator condition, this limits the inferences possible. Saying this, studies of COVID-19 with the comparator group of other forms of viral pneumonia are a useful complement to studies using a general population comparator, as they show whether people with particular risk factors are at risk over and above what they might experience from 'normal' respiratory viruses, which might inform the level of additional precautions they could consider taking.

Finally, appropriately adjusted multivariable analyses should be prioritised, in order to separate the implications of different risk factors and to infer true causal relationships, for example exploring specific markers of comorbidity severity and control, such as the use of specific medications. Early clinical studies during pandemics are critically important and published rapidly under extremely difficult circumstances, but we would argue that highquality epidemiological studies should also be seen as a priority, and that emergency response plans should include provision of appropriate epidemiological and statistical expertise.

\section{Conclusions}

The volume of literature generated in the short time since the appearance of SARS-CoV-2 has been considerable. Many studies have sought to document the risk factors for COVID19 disease, disease severity and mortality. Age was the only risk factor based on robust studies and with a consistent body of evidence. Mechanistic studies are required to understand why age is such an important risk factor. At the start of pandemics, large, 
standardised, studies using multivariable analyses - e.g. using national surveillance data are urgently needed in order to inform stratified approaches to rapidly protecting the population groups most at risk. 


\section{List of abbreviations}

ACE2- Angiotensin-Converting Enzyme 2

ARDS- acute respiratory distress syndrome

BMI- body mass index

CDC- Center for Disease Control and Prevention

COPD- chronic obstructive pulmonary disease

COVID-19- coronavirus disease-19

CT- computed tomography

DIC- disseminated intravascular coagulation

$\mathrm{FiO}_{2}$ - inspired oxygen fraction

ICNARC- intensive care national audit and research centre

ICU- intensive care unit

IL- interleukin

ISARIC- International Severe Acute Respiratory and Emerging Infections Consortium

LRT- lower respiratory tract

MERS- Middle Eastern Respiratory Syndrome

MS- multiple sclerosis

N/A- not applicable

$\mathrm{PaO}_{2}$ - arterial partial pressure of oxygen

PCR- polymerase chain reaction

RAS- renin-angiotensin system

RR- respiratory rate

SARS- Severe Acute Respiratory Syndrome

SARS-CoV-2- Severe Acute Respiratory Syndrome coronavirus-2

$\mathrm{SpO}_{2}$ - oxygen saturation

TMPRSS2- Transmembrane Serine Protease 2

URT- upper respiratory tract 


\section{Declarations}

\section{Ethics approval and consent to participate}

This is a systematic review and therefore presents secondary data. No ethical approvals were required.

\section{Consent for publication}

Not applicable.

\section{Availability of data and materials}

Data sharing is not applicable to this article as no datasets were generated or analysed during the current study.

\section{Competing interests}

CR is a member of the UK SPI-M committee and the Commission Human Medicines COVID-19 Vaccine Safety Working Group. JM is Incident Director for COVID-19 at Public Health Scotland and reports no conflicts of interest. LDR serves on a number of Scottish Government Advisory Groups, including COVID-19. MW is a member of the SPI-M advisory committee for the UK Government and the Covid-19 Advisory Group for the Scottish Government. AS is a member of the Scottish Government's Chief Medical Officer's COVID19 Advisory Group. The views represented in this article do not represent the views of the UK or Scottish Government. All other authors declare that they have no competing interests.

\section{Funding}

HRS and MF are supported by the Medical Research Council [MR/R008345/1]. CJ's salary came through MRC core funding MC_UU_12023/26. SJS is funded by the Wellcome Trust [WT 209560/Z/17/Z]. CRS has received funding from the Medical Research Council 
[MR/R008345/1], the National Institute for Health Research [11/46/23] and the New Zealand Health Research Council [20/1018] and Ministry for Business, Innovation and Employment. EV is funded by the Medical Research Council [MR/R008345/1] through the EAVE II grant and supported by the Scottish Government. We also acknowledge the support of HDR UK. The views and opinions expressed here are those of the authors and do not necessarily reflect those of the Health Technology Assessment programme, NIHR, NHS, or the UK Department of Health.

\section{Authors' contributions}

HRS, MF and AZ conceived of the work. HRS, MF, CJ, EV and CS designed the work. MF, CJ, HRS and EV acquired and interpreted the data. HRS and MF drafted the work and all other authors substantively revised it. All authors approve the submitted version of the manuscript. All authors agree both to be personally accountable for the author's own contributions and to ensure that questions related to the accuracy or integrity of any part of the work, even ones in which the author was not personally involved, are appropriately investigated, resolved, and the resolution documented in the literature

\section{Acknowledgements}

Not applicable. 


\section{References}

1. World Health Organization. WHO Director-General's opening remarks at the media briefing on COVID-19 2020 [updated 11th March 2020. Available from:

\section{https://www.who.int/dg/speeches/detail/who-director-general-s-opening-remarks-at-the-}

\section{media-briefing-on-covid-19---11-march-2020.}

2. CDC COVID-19 Response Team. Severe Outcomes Among Patients with Coronavirus Disease 2019 (COVID-19)- United States, February 12-March 16, 2020. Morbidity and Mortality Weekly Report,. 2020;69.

3. Wu JT, Leung K, Bushman M, Kishore N, Niehus R, de Salazar PM, et al. Estimating clinical severity of COVID-19 from the transmission dynamics in Wuhan, China. Nature Medicine. 2020.

4. Ortiz JR, Perut M, Dumolard L, Wijesinghe PR, Jorgensen P, Ropero AM, et al. A global review of national influenza immunization policies: Analysis of the 2014 WHO/UNICEF Joint Reporting Form on immunization. Vaccine. 2016;34(45):5400-5.

5. NHS Digital. Coronavirus (COVID-19): Shielded patients list 2020 [Available from:

\section{https://digital.nhs.uk/coronavirus/shielded-patient-list.}

6. Health Protection Surveillance Centre. Guidance for Vulnerable Groups 2020 [Available from: https://www.hpsc.ie/a-

\section{z/respiratory/coronavirus/novelcoronavirus/guidance/vulnerablegroupsguidance/}

7. van Bunnik BAD, Morgan ALK, Bessell P, Calder-Gerver G, Zhang F, Haynes S, et al. Segmentation and shielding of the most vulnerable members of the population as elements of an exit strategy from COVID-19 lockdown. MedRxiv. 2020.

8. Ganguli-Mitra A, Young I, Engelmann L, Harper I, McCormack D, Marsland R, et al. Segmenting communities as public health strategy: a view from the social sciences and humanities. Wellcome Open Research. 2020;5(104).

9. NHS Digital. Statement for people who think they have inaccurately been sent communication about being vulnerable to Coronavirus 2020 [updated 24th March 2020. 
Available from: $\underline{\text { https://digital.nhs.uk/news-and-events/latest-news/statement-on-coronavirus- }}$ communications.

10. Public Health England. Guidance on social distancing for everyone in the UK and protecting older people and vulnerable adults 2020 [updated 30th March 2020. Available from: https://www.gov.uk/government/publications/covid-19-guidance-on-social-distancingand-for-vulnerable-people/guidance-on-social-distancing-for-everyone-in-the-uk-andprotecting-older-people-and-vulnerable-adults.

11. Cabinet Office. Staying alert and safe (social distancing) 2020 [Available from: https://www.gov.uk/government/publications/staying-alert-and-safe-social-distancing/stayingalert-and-safe-social-distancing\#protecting-different-groups-of-people.

12. Public Health Scotland. Search criteria for highest risk patients for shielding. Version 4.02020 [Available from: https://hpspubsrepo.blob.core.windows.net/hpswebsite/nss/3008/documents/1 covid-19-search-criteria-highest-risk-patients.pdf. 13. Zheng YY, Ma YT, Zhang JY, Xie X. COVID-19 and the cardiovascular system. Nat Rev Cardiol. 2020;17(5):259-60.

14. World Health Organization. Clinical management of severe acute respiratory infection (SARI) when COVID-19 disease is suspected Interim guidance 2020 [updated 13th March 2020. Available from: https://www.who.int/publications-detail/clinical-management-of-severeacute-respiratory-infection-when-novel-coronavirus-(ncov)-infection-is-suspected.

15. Downs SH, Black N. The feasibility of creating a checklist for the assessment of the methodological quality both of randomised and non-randomised studies of health care interventions. J Epidemiol Community Health. 1998;52(6):377-84.

16. Deeks JJ, Dinnes J, D'Amico R, Sowden AJ, Sakarovitch C, Song F, et al. Evaluating non-randomised intervention studies. Health Technol Assess. 2003;7(27):iii-x, 1-173.

17. Westreich D, Greenland S. The table 2 fallacy: presenting and interpreting confounder and modifier coefficients. Am J Epidemiol. 2013;177(4):292-8.

18. Cai Q, Huang D, Ou P, Yu H, Zhu Z, Xia Z, et al. COVID-19 in a designated infectious diseases hospital outside Hubei Province, China. Allergy. 2020. 
19. Chen J, Qi T, Liu L, Ling Y, Qian Z, Li T, et al. Clinical progression of patients with COVID-19 in Shanghai, China. Journal of Infection. 2020;80(5):e1-e6.

20. Chen T, Wu D, Chen H, Yan W, Yang D, Chen G, et al. Clinical characteristics of 113 deceased patients with coronavirus disease 2019: Retrospective study. The BMJ. 2020;368(no pagination).

21. Chen X, Yang Y, Huang M, Liu L, Zhang X, Xu J, et al. Differences between COVID19 and suspected then confirmed SARS-CoV-2-negative pneumonia: a retrospective study from a single center. Journal of medical virology. 2020;01.

22. Chen G, Wu D, Guo W, Cao Y, Huang D, Wang H, et al. Clinical and immunological features of severe and moderate coronavirus disease 2019. J Clin Invest. 2020;130(5):26209.

23. Cheng Z, Lu Y, Cao Q, Qin L, Pan Z, Yan F, et al. Clinical Features and Chest CT Manifestations of Coronavirus Disease 2019 (COVID-19) in a Single-Center Study in Shanghai, China. AJR American journal of roentgenology. 2020.

24. Epidemiology Working Group for Ncip Epidemic Response CCfDC, Prevention. [The epidemiological characteristics of an outbreak of 2019 novel coronavirus diseases (COVID19) in China]. Zhonghua Liu Xing Bing Xue Za Zhi. 2020;41(2):145-51.

25. Fan BE, Chong VCL, Chan SSW, Lim GH, Lim KGE, Tan GB, et al. Hematologic parameters in patients with COVID-19 infection. Am J Hematol. 2020.

26. Grasselli G, Zangrillo A, Zanella A, Antonelli M, Cabrini L, Castelli A, et al. Baseline Characteristics and Outcomes of 1591 Patients Infected with SARS-CoV-2 Admitted to ICUs of the Lombardy Region, Italy. JAMA Journal of the American Medical Association. 2020. 27. Han H, Xie L, Liu R, Yang J, Liu F, Wu K, et al. Analysis of heart injury laboratory parameters in 273 COVID-19 patients in one hospital in Wuhan, China. Journal of Medical Virology. 2020.

28. Huang C, Wang Y, Li X, Ren L, Zhao J, Hu Y, et al. Clinical features of patients infected with 2019 novel coronavirus in Wuhan, China. The Lancet. 2020;395(10223):497506. 
29. Intensive Care National Audit and Research Centre. ICNARC report on COVID-19 in critical care 2020 [Available from:

https://www.google.com/url?sa=t\&rct=i\&q=\&esrc=s\&source=web\&cd=\&cad=rja\&uact=8\&ved =2ahUKEwjS4MK86NbpAhVPQ0EAHQ3dD5gQFjAAegQIBhAB\&url=https\%3A\%2F\%2Fww w.icnarc.org\%2FDataServices\%2FAttachments\%2FDownload\%2Fc5a62b13-6486-ea11-

\section{5-00505601089b\&usg=AOvVaw3iovn0oEBhP6xPnV27|9HR.}

30. Liang W, Guan W, Chen R, Wang W, Li J, Xu K, et al. Cancer patients in SARS-CoV2 infection: a nationwide analysis in China. The Lancet Oncology. 2020;21(3):335-7.

31. Liu R, Ma Q, Han H, Su H, Liu F, Wu K, et al. The value of urine biochemical parameters in the prediction of the severity of coronavirus disease 2019. Clinical chemistry and laboratory medicine. 2020;14.

32. Liu R, Han H, Liu F, Lv Z, Wu K, Liu Y, et al. Positive rate of RT-PCR detection of SARS-CoV-2 infection in 4880 cases from one hospital in Wuhan, China, from Jan to Feb 2020. Clin Chim Acta. 2020;505:172-5.

33. Qiu H, Wu J, Hong L, Luo Y, Song Q, Chen D. Clinical and epidemiological features of 36 children with coronavirus disease 2019 (COVID-19) in Zhejiang, China: an observational cohort study. The Lancet Infectious Diseases. 2020.

34. Ruan Q, Yang K, Wang W, Jiang L, Song J. Clinical predictors of mortality due to COVID-19 based on an analysis of data of 150 patients from Wuhan, China. Intensive Care Med. 2020.

35. Shi Y, Yu X, Zhao H, Wang H, Zhao R, Sheng J. Host susceptibility to severe COVID-19 and establishment of a host risk score: findings of 487 cases outside Wuhan. Crit Care. 2020;24(1):108.

36. Simonnet A, Chetboun M, Poissy J, Raverdy V, Noulette J, Duhamel A, et al. High prevalence of obesity in severe acute respiratory syndrome coronavirus-2 (SARS-CoV-2) requiring invasive mechanical ventilation. Obesity. 2020;09.

37. Tian S, Hu N, Lou J, Chen K, Kang X, Xiang Z, et al. Characteristics of COVID-19 infection in Beijing. Journal of Infection. 2020. 
38. Wan S, Xiang Y, Fang W, Zheng Y, Li B, Hu Y, et al. Clinical features and treatment of COVID-19 patients in northeast Chongqing. Journal of Medical Virology. 2020.

39. Wang C, Horby PW, Hayden FG, Gao GF. A novel coronavirus outbreak of global health concern. Lancet. 2020;395(10223):470-3.

40. Wang D, Hu B, Hu C, Zhu F, Liu X, Zhang J, et al. Clinical Characteristics of 138 Hospitalized Patients with 2019 Novel Coronavirus-Infected Pneumonia in Wuhan, China. JAMA Journal of the American Medical Association. 1061;323(11):1061-9.

41. Wang L, Li X, Chen H, Yan S, Li D, Li Y, et al. Coronavirus Disease 19 Infection Does Not Result in Acute Kidney Injury: An Analysis of 116 Hospitalized Patients from Wuhan, China. American journal of nephrology. 2020.

42. Wang Z, Yang B, Li Q, Wen L, Zhang R. Clinical Features of 69 Cases with Coronavirus Disease 2019 in Wuhan, China. Clinical infectious diseases : an official publication of the Infectious Diseases Society of America. 2020;16.

43. Wu C, Chen X, Cai Y, Xia J, Zhou X, Xu S, et al. Risk Factors Associated With Acute Respiratory Distress Syndrome and Death in Patients With Coronavirus Disease 2019 Pneumonia in Wuhan, China. JAMA Intern Med. 2020.

44. Wu Z, McGoogan JM. Characteristics of and Important Lessons from the Coronavirus Disease 2019 (COVID-19) Outbreak in China: Summary of a Report of 72314 Cases from the Chinese Center for Disease Control and Prevention. JAMA Journal of the American Medical Association. 1239;323(13):1239-42.

45. Yang X, Yu Y, Xu J, Shu H, Xia J, Liu H, et al. Clinical course and outcomes of critically ill patients with SARS-CoV-2 pneumonia in Wuhan, China: a single-centered, retrospective, observational study. Lancet Respir Med. 2020.

46. Yuan M, Yin W, Tao Z, Tan W, Hu Y. Association of radiologic findings with mortality of patients infected with 2019 novel coronavirus in Wuhan, China. PLoS ONE. 2020;15(3). 47. Zhang JJ, Dong X, Cao YY, Yuan YD, Yang YB, Yan YQ, et al. Clinical characteristics of 140 patients infected with SARS-CoV-2 in Wuhan, China. Allergy: European Journal of Allergy and Clinical Immunology. 2020. 
48. Zhang G, Zhang J, Wang B, Zhu X, Wang Q, Qiu S. Analysis of clinical characteristics and laboratory findings of 95 cases of 2019 novel coronavirus pneumonia in Wuhan, China: a retrospective analysis. Respir Res. 2020;21(1):74.

49. Zhang R, Ouyang H, Fu L, Wang S, Han J, Huang K, et al. CT features of SARSCoV-2 pneumonia according to clinical presentation: a retrospective analysis of 120 consecutive patients from Wuhan city. Eur Radiol. 2020.

50. Zhou F, Yu T, Du R, Fan G, Liu Y, Liu Z, et al. Clinical course and risk factors for mortality of adult inpatients with COVID-19 in Wuhan, China: a retrospective cohort study. The Lancet. 1054;395(10229):1054-62.

51. Price-Haywood EG, Burton J, Fort D, Seoane L. Hospitalization and Mortality among Black Patients and White Patients with Covid-19. N Engl J Med. 2020.

52. Docherty AB, Harrison EM, Green CA, Hardwick HE, Pius R, Norman L, et al. Features of 20133 UK patients in hospital with covid-19 using the ISARIC WHO Clinical Characterisation Protocol: prospective observational cohort study. BMJ. 2020;369:m1985.

53. Chen J. Pathogenicity and transmissibility of 2019-nCoV-A quick overview and comparison with other emerging viruses. Microbes Infect. 2020;22(2):69-71.

54. Gengler IW, J.C.; Speth, M.M.; Sedaghat A.R.;. Sinonasal pathophysiology of SARSCoV-2 and COVID-19: A systematic review of the current evidence. Laryngoscope Investigative Otolaryngology. 2020:1-6.

55. Chu H, Chan JF, Wang Y, Yuen TT, Chai Y, Hou Y, et al. Comparative replication and immune activation profiles of SARS-CoV-2 and SARS-CoV in human lungs: an ex vivo study with implications for the pathogenesis of COVID-19. Clin Infect Dis. 2020.

56. Fu Y, Cheng Y, Wu Y. Understanding SARS-CoV-2-Mediated Inflammatory Responses: From Mechanisms to Potential Therapeutic Tools. Virol Sin. 2020.

57. Kumar VA, A.K.; Aster, J.C.; . Robbins \& Cotran Pathologic Basis of Disease, 9e (Robbins Pathology) 2014. 1408 p. 
58. Pangrazzi L, Meryk A, Naismith E, Koziel R, Lair J, Krismer M, et al. "Inflamm-aging" influences immune cell survival factors in human bone marrow. Eur J Immunol. 2017;47(3):481-92.

59. Bunyavanich S, Do A, Vicencio A. Nasal Gene Expression of Angiotensin-Converting Enzyme 2 in Children and Adults. JAMA. 2020.

60. European Centre for Disease Prevention and Control. ECDC launches new weekly COVID-19 surveillance report 2020 [Available from: https://www.ecdc.europa.eu/en/newsevents/ecdc-launches-new-weekly-covid-19-surveillance-report.

61. McGlothlin AE, Lewis RJ. Minimal clinically important difference: defining what really matters to patients. JAMA. 2014;312(13):1342-3.

62. International Severe Acute Respiratory and Emerging Infection Consortium. COVID19 Clinical Research Resources 2020 [Available from: https://isaric.tghn.org/covid-19clinical-research-resources/. 


\section{Figure legends}

\section{Figure 1: PRISMA flow chart of selection}

\section{Tables}

Table 1: UK risk groupings for COVID-19 disease

\begin{tabular}{|c|c|}
\hline At risk of severe illness & Shielding \\
\hline \multicolumn{2}{|l|}{$\begin{array}{l}\text { Aged } 70 \text { or older (regardless of medical } \\
\text { conditions) }\end{array}$} \\
\hline $\begin{array}{l}\text { Aged under } 70 \text { and }^{*} \\
\text { Chronic (long-term) mild to moderate } \\
\text { respiratory diseases, such as asthma, } \\
\text { COPD, emphysema or bronchitis }\end{array}$ & $\begin{array}{l}\text { People with severe chest conditions such as cystic } \\
\text { fibrosis or severe asthma (requiring hospital } \\
\text { admissions or courses of steroid tablets) }\end{array}$ \\
\hline \multicolumn{2}{|l|}{$\begin{array}{l}\text { Chronic heart disease, such as heart } \\
\text { failure }\end{array}$} \\
\hline Chronic kidney disease & $\begin{array}{l}\text { People with severe diseases of body systems, such } \\
\text { as severe kidney disease (dialysis) }\end{array}$ \\
\hline \multicolumn{2}{|l|}{ Chronic liver disease, such as hepatitis } \\
\hline \multicolumn{2}{|l|}{$\begin{array}{l}\text { Chronic neurological conditions, such as } \\
\text { Parkinson's disease, motor neurone } \\
\text { disease, MS, a learning disability or } \\
\text { cerebral palsy }\end{array}$} \\
\hline \multicolumn{2}{|l|}{ Diabetes } \\
\hline \multirow{3}{*}{$\begin{array}{l}\text { A weakened immune system as the } \\
\text { result of conditions such as HIV and } \\
\text { AIDS, or medicines such as steroid } \\
\text { tablets }\end{array}$} & $\begin{array}{l}\text { People who have received an organ transplant and } \\
\text { remain on ongoing immunosuppression medication }\end{array}$ \\
\hline & $\begin{array}{l}\text { People with cancer who are undergoing active } \\
\text { chemotherapy or radiotherapy }\end{array}$ \\
\hline & $\begin{array}{l}\text { People with cancers of the blood or bone marrow } \\
\text { such as leukaemia who are at any stage of } \\
\text { treatment }\end{array}$ \\
\hline \multicolumn{2}{|l|}{$\begin{array}{l}\text { Being seriously overweight (a BMI of } 40 \\
\text { or above) }\end{array}$} \\
\hline Those who are pregnant & \\
\hline
\end{tabular}




\begin{tabular}{|c|c|c|c|c|c|c|c|c|}
\hline Author & Type of study & Country & Study population & $\begin{array}{c}\text { Overall } \\
\text { number } \\
\text { of } \\
\text { patients }\end{array}$ & $\begin{array}{l}\text { Analytical } \\
\text { method } \\
\text { used }\end{array}$ & $\begin{array}{c}\text { Factors } \\
\text { included in } \\
\text { multivariable } \\
\text { model }\end{array}$ & $\begin{array}{l}\text { Disease, } \\
\text { disease } \\
\text { severity, } \\
\text { or death }\end{array}$ & Definition of severity \\
\hline Cai (18) & $\begin{array}{l}\text { Retrospective } \\
\text { cohort }\end{array}$ & China & $\begin{array}{l}\text { Hospitalised } \\
\text { patients, single } \\
\text { hospital }\end{array}$ & 298 & $\begin{array}{l}\text { Univariable; } \\
\text { logistic } \\
\text { regression }\end{array}$ & $\begin{array}{l}\text { N/A; age, sex, } \\
\text { comorbidities, } \\
\text { clinical } \\
\text { markers, travel } \\
\text { history }\end{array}$ & $\begin{array}{l}\text { Disease } \\
\text { severity }\end{array}$ & $\begin{array}{l}\text { As per the international } \\
\text { guidelines for community- } \\
\text { acquired pneumonia, with a } \\
\text { scoring system based on } \\
\text { demographics, comorbid illness, } \\
\text { physical examination findings, } \\
\text { and laboratory and radiographic } \\
\text { findings }\end{array}$ \\
\hline Chen (19) & $\begin{array}{l}\text { Retrospective } \\
\text { cohort }\end{array}$ & China & $\begin{array}{l}\text { Hospitalised } \\
\text { patients, single } \\
\text { hospital }\end{array}$ & 249 & $\begin{array}{l}\text { Logistic } \\
\text { regression }\end{array}$ & $\begin{array}{l}\text { Age, sex, } \\
\text { comorbidities } \\
\text { and a range of } \\
\text { clinical } \\
\text { measures }\end{array}$ & $\begin{array}{l}\text { Disease } \\
\text { severity }\end{array}$ & ICU admission \\
\hline Chen (20) & $\begin{array}{l}\text { Retrospective } \\
\text { cohort with a } \\
\text { nested case- } \\
\text { control study }\end{array}$ & China & $\begin{array}{l}\text { Hospitalised } \\
\text { patients } \\
\text { (moderately, } \\
\text { severely or } \\
\text { critically ill), single } \\
\text { hospital }\end{array}$ & 274 & Univariable & $\mathrm{N} / \mathrm{A}$ & Death & $\mathrm{N} / \mathrm{A}$ \\
\hline Chen (21) & Case-control & China & $\begin{array}{l}\text { COVID-19 vs. } \\
\text { pneumonia } \\
\text { negative for SARS- } \\
\text { CoV-2 }\end{array}$ & $\begin{array}{l}104(78 \\
\text { COVID- } \\
19)\end{array}$ & Univariable & $\mathrm{N} / \mathrm{A}$ & Disease & N/A \\
\hline Chen (22) & $\begin{array}{l}\text { Retrospective } \\
\text { cohort }\end{array}$ & China & $\begin{array}{l}\text { Hospitalised } \\
\text { patients, single } \\
\text { hospital }\end{array}$ & 21 & Univariable & N/A & $\begin{array}{l}\text { Disease } \\
\text { severity }\end{array}$ & $\begin{array}{l}\text { Severe meets any of the } \\
\text { following criteria- respiratory } \\
\text { distress, RR } \geq 30 \text { breaths/min; } \\
\mathrm{SpO}_{2} \leq 93 \% \text { at rest; and } \\
\mathrm{PaO}_{2} / \mathrm{FIO}_{2} \leq 300 \text {. Patients with } \\
\text { greater than } 50 \% \text { lesion } \\
\text { progression within } 24 \text { to } 48 \\
\text { hours in pulmonary imaging. }\end{array}$ \\
\hline
\end{tabular}




\begin{tabular}{|c|c|c|c|c|c|c|c|c|}
\hline Author & Type of study & Country & Study population & $\begin{array}{c}\text { Overall } \\
\text { number } \\
\text { of } \\
\text { patients }\end{array}$ & $\begin{array}{c}\text { Analytical } \\
\text { method } \\
\text { used }\end{array}$ & $\begin{array}{c}\text { Factors } \\
\text { included in } \\
\text { multivariable } \\
\text { model }\end{array}$ & $\begin{array}{l}\text { Disease, } \\
\text { disease } \\
\text { severity, } \\
\text { or death }\end{array}$ & Definition of severity \\
\hline $\begin{array}{l}\text { Cheng } \\
(23)\end{array}$ & Case-control & China & $\begin{array}{l}\text { Patients presenting } \\
\text { with fever } \\
\text { diagnosed with } \\
\text { pneumonia by } \\
\text { specialists with } \\
\text { chest CT scans }\end{array}$ & $\begin{array}{l}38(11 \\
\text { COVID- } \\
19)\end{array}$ & Univariable & N/A & Disease & $\mathrm{N} / \mathrm{A}$ \\
\hline $\begin{array}{l}\text { Chinese } \\
\text { CDC (24) }\end{array}$ & $\begin{array}{l}\text { Retrospective } \\
\text { cohort }\end{array}$ & China & $\begin{array}{l}\text { Nationwide } \\
\text { surveillance }\end{array}$ & 72314 & Univariable & $\mathrm{N} / \mathrm{A}$ & Death & $\mathrm{N} / \mathrm{A}$ \\
\hline Fan (25) & $\begin{array}{l}\text { Retrospective } \\
\text { cohort }\end{array}$ & Singapore & $\begin{array}{l}\text { Hospitalised } \\
\text { patients, National } \\
\text { Centre for } \\
\text { Infectious } \\
\text { Diseases }\end{array}$ & 67 & Univariable & $\mathrm{N} / \mathrm{A}$ & $\begin{array}{l}\text { Disease } \\
\text { severity }\end{array}$ & ICU admission \\
\hline $\begin{array}{l}\text { Grasselli } \\
(26)\end{array}$ & $\begin{array}{l}\text { Prospective } \\
\text { cohort with a } \\
\text { nested case- } \\
\text { control study }\end{array}$ & Italy & $\begin{array}{l}\text { Hospitalised in ICU } \\
\text { across } 72 \text { hospitals }\end{array}$ & 1591 & Univariable & $\mathrm{N} / \mathrm{A}$ & Death & $\mathrm{N} / \mathrm{A}$ \\
\hline
\end{tabular}




\begin{tabular}{|c|c|c|c|c|c|c|c|c|}
\hline Author & Type of study & Country & Study population & $\begin{array}{c}\text { Overall } \\
\text { number } \\
\text { of } \\
\text { patients }\end{array}$ & $\begin{array}{l}\text { Analytical } \\
\text { method } \\
\text { used }\end{array}$ & $\begin{array}{c}\text { Factors } \\
\text { included in } \\
\text { multivariable } \\
\text { model }\end{array}$ & $\begin{array}{l}\text { Disease, } \\
\text { disease } \\
\text { severity, } \\
\text { or death }\end{array}$ & Definition of severity \\
\hline Han (27) & $\begin{array}{l}\text { Retrospective } \\
\text { cohort }\end{array}$ & China & $\begin{array}{l}\text { Hospitalised } \\
\text { patients, single } \\
\text { hospital }\end{array}$ & 273 & Univariable & N/A & $\begin{array}{l}\text { Disease } \\
\text { severity }\end{array}$ & $\begin{array}{l}\text { Severe met at least one of the } \\
\text { following conditions: a) } \\
\text { shortness of breath, RR } \geq 30 \\
\text { times/min, b) oxygen saturation } \\
\text { (resting state) } \leq 93 \% \text {, or c) } \\
\mathrm{PaO}_{2} / \mathrm{FiO} 2 \leq 300 \mathrm{~mm} \mathrm{Hg} \text {., in } \\
\text { addition to positive SARS-CoV-2 } \\
\text { RNA nucleic acid test by } \\
\text { Reverse transcription } \\
\text { polymerase chain reaction, } \\
\text { fever, or other respiratory } \\
\text { symptoms (the typical CT image } \\
\text { abnormities of viral pneumonia } \\
\text { were optional). Critical patients } \\
\text { also needed to meet at least one } \\
\text { of the extra following conditions: } \\
\text { a) respiratory failure that needs } \\
\text { to receive mechanical } \\
\text { ventilation; b) shock; and c) } \\
\text { multiple organ failure that need } \\
\text { to be transferred to the ICU. }\end{array}$ \\
\hline $\begin{array}{l}\text { Huang } \\
(28)\end{array}$ & $\begin{array}{l}\text { Retrospective } \\
\text { cohort }\end{array}$ & China & $\begin{array}{l}\text { Hospitalised } \\
\text { patients, single } \\
\text { hospital }\end{array}$ & 41 & Univariable & $\mathrm{N} / \mathrm{A}$ & $\begin{array}{l}\text { Disease } \\
\text { severity }\end{array}$ & ICU admission \\
\hline $\begin{array}{l}\text { ICNARC } \\
(29)\end{array}$ & $\begin{array}{l}\text { Case-control } \\
\text { (disease) / } \\
\text { Prospective } \\
\text { cohort } \\
\text { (disease } \\
\text { severity) }\end{array}$ & $\begin{array}{l}\text { England, } \\
\text { Northern } \\
\text { Ireland } \\
\text { and Wales }\end{array}$ & $\begin{array}{l}\text { Hospitalised } \\
\text { patients in ICU } \\
\text { across a network } \\
\text { of hospitals }\end{array}$ & $\begin{array}{l}12502 \\
(6720 \\
\text { COVID- } \\
19)\end{array}$ & Univariable & N/A & $\begin{array}{l}\text { Disease; } \\
\text { Disease } \\
\text { severity }\end{array}$ & $\begin{array}{l}\text { Receiving advanced, as } \\
\text { opposed to basic, respiratory } \\
\text { support }\end{array}$ \\
\hline
\end{tabular}




\begin{tabular}{|c|c|c|c|c|c|c|c|c|}
\hline Author & Type of study & Country & Study population & $\begin{array}{c}\text { Overall } \\
\text { number } \\
\text { of } \\
\text { patients }\end{array}$ & $\begin{array}{l}\text { Analytical } \\
\text { method } \\
\text { used }\end{array}$ & $\begin{array}{c}\text { Factors } \\
\text { included in } \\
\text { multivariable } \\
\text { model }\end{array}$ & $\begin{array}{l}\text { Disease, } \\
\text { disease } \\
\text { severity, } \\
\text { or death }\end{array}$ & Definition of severity \\
\hline Liang (30) & $\begin{array}{l}\text { Prospective } \\
\text { cohort }\end{array}$ & China & $\begin{array}{l}\text { Hospitalised } \\
\text { patients across } \\
575 \text { hospitals }\end{array}$ & 1590 & $\begin{array}{l}\text { Logistic } \\
\text { regression; } \\
\text { Cox } \\
\text { regression }\end{array}$ & $\begin{array}{l}\text { Logistic model } \\
\text { adjusted for } \\
\text { age, sex, } \\
\text { smoking } \\
\text { history, } \\
\text { comorbidities, } \\
\text { cancer }\end{array}$ & $\begin{array}{l}\text { Disease } \\
\text { severity, } \\
\text { Death }\end{array}$ & $\begin{array}{l}\text { Invasive ventilation, ICU } \\
\text { admission, death }\end{array}$ \\
\hline Liu (31) & $\begin{array}{l}\text { Retrospective } \\
\text { cohort }\end{array}$ & China & $\begin{array}{l}\text { Hospitalised } \\
\text { patients, single } \\
\text { hospital }\end{array}$ & 119 & Univariable & $\mathrm{N} / \mathrm{A}$ & $\begin{array}{l}\text { Disease } \\
\text { severity }\end{array}$ & $\begin{array}{l}\text { Severe- dyspnoea accompanied } \\
\text { by hypoxemia, sometimes acute } \\
\text { respiratory distress syndrome, } \\
\text { septic shock and multiple organ } \\
\text { failure }\end{array}$ \\
\hline Liu (32) & $\begin{array}{l}\text { Retrospective } \\
\text { cohort }\end{array}$ & China & $\begin{array}{l}\text { Hospitalised } \\
\text { patients, single } \\
\text { hospital }\end{array}$ & 4880 & $\begin{array}{l}\text { Logistic } \\
\text { regression }\end{array}$ & Age, sex & Disease & $N / A$ \\
\hline Qiu (33) & $\begin{array}{l}\text { Retrospective } \\
\text { cohort }\end{array}$ & China & $\begin{array}{l}\text { Hospitalised } \\
\text { paediatric patients, } \\
\text { three hospitals }\end{array}$ & 36 & Univariable & $\mathrm{N} / \mathrm{A}$ & $\begin{array}{l}\text { Disease } \\
\text { severity }\end{array}$ & $\begin{array}{l}\text { Moderate disease (mild was } \\
\text { baseline)- mild pneumonia; } \\
\text { symptoms such as fever, cough, } \\
\text { fatigue, headache, and myalgia; } \\
\text { no complications and } \\
\text { manifestations related to severe } \\
\text { conditions }\end{array}$ \\
\hline Ruan (34) & $\begin{array}{l}\text { Retrospective } \\
\text { cohort with a } \\
\text { nested case- } \\
\text { control study }\end{array}$ & China & $\begin{array}{l}\text { Hospitalised } \\
\text { patients across two } \\
\text { hospitals with a } \\
\text { definitive outcome }\end{array}$ & 150 & Univariable & $\mathrm{N} / \mathrm{A}$ & Death & N/A \\
\hline Shi (35) & $\begin{array}{l}\text { Retrospective } \\
\text { cohort }\end{array}$ & China & $\begin{array}{l}\text { Hospitalised } \\
\text { patients across a } \\
\text { province }\end{array}$ & 487 & $\begin{array}{l}\text { Univariable; } \\
\text { logistic } \\
\text { regression }\end{array}$ & $\begin{array}{l}\text { N/A; age, sex, } \\
\text { hypertension; } \\
\text { full list } \\
\text { unknown }\end{array}$ & $\begin{array}{l}\text { Disease } \\
\text { severity }\end{array}$ & $\begin{array}{l}\text { Severe pneumonia, } \\
\text { characterised by fever, cough, } \\
\text { dyspnoea, bilateral pulmonary } \\
\text { infiltrates, and acute respiratory } \\
\text { injury }\end{array}$ \\
\hline
\end{tabular}




\begin{tabular}{|c|c|c|c|c|c|c|c|c|}
\hline Author & Type of study & Country & Study population & $\begin{array}{c}\text { Overall } \\
\text { number } \\
\text { of } \\
\text { patients }\end{array}$ & $\begin{array}{l}\text { Analytical } \\
\text { method } \\
\text { used }\end{array}$ & $\begin{array}{c}\text { Factors } \\
\text { included in } \\
\text { multivariable } \\
\text { model }\end{array}$ & $\begin{array}{l}\text { Disease, } \\
\text { disease } \\
\text { severity, } \\
\text { or death }\end{array}$ & Definition of severity \\
\hline $\begin{array}{l}\text { Simmonet } \\
(36)\end{array}$ & $\begin{array}{l}\text { Retrospective } \\
\text { cohort }\end{array}$ & France & $\begin{array}{l}\text { Hospitalised } \\
\text { patients in ICU, } \\
\text { single hospital }\end{array}$ & 124 & $\begin{array}{l}\text { Logistic } \\
\text { regression }\end{array}$ & $\begin{array}{l}\text { Age, sex, } \\
\text { diabetes, } \\
\text { hypertension, } \\
\text { BMI }\end{array}$ & $\begin{array}{l}\text { Disease } \\
\text { severity }\end{array}$ & $\begin{array}{l}\text { Receiving invasive mechanical } \\
\text { ventilation, determined when } \\
\text { oxygen therapy }(\geq 10 \mathrm{~L} / \mathrm{min}) \text { with } \\
\text { target } \mathrm{SpO}_{2}(90-94 \%) \text { was } \\
\text { ineffective, and when RR was } \\
\text { above } 25 / \mathrm{min} \text {, with signs of } \\
\text { acute respiratory failure, despite } \\
\text { maximal oxygen therapy }\end{array}$ \\
\hline Tian (37) & $\begin{array}{l}\text { Retrospective } \\
\text { cohort }\end{array}$ & China & $\begin{array}{l}\text { Hospitalised } \\
\text { individuals } \\
\text { transferred from } \\
\text { the hospitals of } \\
\text { Beijing to the } \\
\text { designated } \\
\text { hospitals for } \\
\text { specialist treatment } \\
\text { of infectious } \\
\text { diseases by Beijing } \\
\text { Emergency } \\
\text { Medical Service }\end{array}$ & 262 & Univariable & $\mathrm{N} / \mathrm{A}$ & $\begin{array}{l}\text { Disease } \\
\text { severity }\end{array}$ & $\begin{array}{l}\text { Severe- dyspnoea or respiratory } \\
\text { failure in addition to fever, } \\
\text { respiratory symptoms and } \\
\text { radiographic evidence of } \\
\text { pneumonia }\end{array}$ \\
\hline Wan (38) & $\begin{array}{l}\text { Prospective } \\
\text { cohort }\end{array}$ & China & $\begin{array}{l}\text { Hospitalised } \\
\text { patients, single } \\
\text { hospital }\end{array}$ & 135 & Univariable & $\mathrm{N} / \mathrm{A}$ & $\begin{array}{l}\text { Disease } \\
\text { severity }\end{array}$ & $\begin{array}{l}\text { Severe group- respiratory } \\
\text { distress, } \mathrm{RR} \geq 30 \text { breaths/minute } \\
\text { in a resting state, a mean } \\
\text { oxygen saturation of } \leq 93 \% \text {, and } \\
\text { an } \mathrm{PaO}_{2} / \mathrm{FiO}_{2} \leq 300 \mathrm{mmHg}\end{array}$ \\
\hline $\begin{array}{l}\text { Wang } \\
(39)\end{array}$ & Case-control & China & $\begin{array}{l}\text { Country-wide data } \\
\text { compared to } \\
\text { historic } \\
\text { SARS/MERS }\end{array}$ & $\begin{array}{l}11425 \\
(835 \\
\text { COVID- } \\
19)\end{array}$ & Univariable & $\mathrm{N} / \mathrm{A}$ & Disease & $\mathrm{N} / \mathrm{A}$ \\
\hline $\begin{array}{l}\text { Wang } \\
(40)\end{array}$ & $\begin{array}{l}\text { Retrospective } \\
\text { cohort }\end{array}$ & China & $\begin{array}{l}\text { Hospitalised } \\
\text { patients, single } \\
\text { hospital }\end{array}$ & 138 & Univariable & $\mathrm{N} / \mathrm{A}$ & $\begin{array}{l}\text { Disease } \\
\text { severity }\end{array}$ & ICU admission \\
\hline
\end{tabular}




\begin{tabular}{|c|c|c|c|c|c|c|c|c|}
\hline Author & Type of study & Country & Study population & $\begin{array}{c}\text { Overall } \\
\text { number } \\
\text { of } \\
\text { patients }\end{array}$ & $\begin{array}{c}\text { Analytical } \\
\text { method } \\
\text { used }\end{array}$ & $\begin{array}{c}\text { Factors } \\
\text { included in } \\
\text { multivariable } \\
\text { model }\end{array}$ & $\begin{array}{l}\text { Disease, } \\
\text { disease } \\
\text { severity, } \\
\text { or death }\end{array}$ & Definition of severity \\
\hline $\begin{array}{l}\text { Wang } \\
(41)\end{array}$ & $\begin{array}{l}\text { Prospective } \\
\text { cohort }\end{array}$ & China & $\begin{array}{l}\text { Hospitalised } \\
\text { patients, single } \\
\text { hospital }\end{array}$ & 116 & Univariable & N/A & $\begin{array}{l}\text { Disease } \\
\text { severity }\end{array}$ & $\begin{array}{l}\text { Severe- fever or suspected } \\
\text { respiratory infection, plus one of } \\
\text { the following: } \mathrm{RR}>30 \\
\text { breaths/min; severe respiratory } \\
\text { distress; or } \mathrm{SpO}_{2} \leq 93 \% \text { on room } \\
\text { air }\end{array}$ \\
\hline $\begin{array}{l}\text { Wang } \\
(42)\end{array}$ & $\begin{array}{l}\text { Cross- } \\
\text { sectional }\end{array}$ & China & $\begin{array}{l}\text { Hospitalised } \\
\text { patients, single } \\
\text { hospital }\end{array}$ & 69 & Univariable & $\mathrm{N} / \mathrm{A}$ & $\begin{array}{l}\text { Disease } \\
\text { severity }\end{array}$ & $\mathrm{SpO}_{2}<90 \%$ \\
\hline Wu (43) & $\begin{array}{l}\text { Retrospective } \\
\text { cohort }\end{array}$ & China & $\begin{array}{l}\text { Hospitalised } \\
\text { patients, single } \\
\text { hospital }\end{array}$ & 201 & $\begin{array}{l}\text { Univariable; } \\
\text { Cox } \\
\text { regression }\end{array}$ & N/A & $\begin{array}{l}\text { Disease } \\
\text { severity, } \\
\text { Death }\end{array}$ & ARDS, mechanical ventilation \\
\hline Wu (44) & $\begin{array}{l}\text { Prospective } \\
\text { cohort }\end{array}$ & China & Country-wide data & 44672 & Univariable & N/A & Death & N/A \\
\hline Yang (45) & $\begin{array}{l}\text { Retrospective } \\
\text { cohort }\end{array}$ & China & $\begin{array}{l}\text { Hospitalised } \\
\text { patients, single } \\
\text { hospital, admitted } \\
\text { to ICU }\end{array}$ & 52 & $\begin{array}{l}\text { Univariable; } \\
\text { Cox } \\
\text { regression }\end{array}$ & N/A & Death & N/A \\
\hline Yuan (46) & $\begin{array}{l}\text { Retrospective } \\
\text { cohort }\end{array}$ & China & $\begin{array}{l}\text { Hospitalised } \\
\text { patients, single } \\
\text { hospital }\end{array}$ & 27 & Univariable & N/A & Death & N/A \\
\hline $\begin{array}{l}\text { Zhang } \\
\text { (47) }\end{array}$ & $\begin{array}{l}\text { Retrospective } \\
\text { cohort }\end{array}$ & China & $\begin{array}{l}\text { Hospitalised } \\
\text { patients, single } \\
\text { hospital }\end{array}$ & 140 & Univariable & N/A & $\begin{array}{l}\text { Disease } \\
\text { severity }\end{array}$ & $\begin{array}{l}\text { Severe COVID- } 19 \text { was } \\
\text { designated when the patients } \\
\text { had one of the following criteria: } \\
\text { (a) respiratory distress with } \\
\text { respiratory frequency } \geq 30 / \mathrm{min} \text {; } \\
\text { (b) pulse oximeter oxygen } \\
\text { saturation } \leq 93 \% \text { at rest; and (c) } \\
\text { oxygenation index }\left(\mathrm{PaO}_{2} / \mathrm{FiO}_{2}\right) \leq \\
300 \mathrm{~mm} \mathrm{Hg} \text {. }\end{array}$ \\
\hline
\end{tabular}




\begin{tabular}{|c|c|c|c|c|c|c|c|c|}
\hline Author & Type of study & Country & Study population & $\begin{array}{l}\text { Overall } \\
\text { number } \\
\text { of } \\
\text { patients }\end{array}$ & $\begin{array}{l}\text { Analytical } \\
\text { method } \\
\text { used }\end{array}$ & $\begin{array}{c}\text { Factors } \\
\text { included in } \\
\text { multivariable } \\
\text { model }\end{array}$ & $\begin{array}{l}\text { Disease, } \\
\text { disease } \\
\text { severity, } \\
\text { or death }\end{array}$ & Definition of severity \\
\hline $\begin{array}{l}\text { Zhang } \\
\text { (48) }\end{array}$ & $\begin{array}{l}\text { Retrospective } \\
\text { cohort }\end{array}$ & China & $\begin{array}{l}\text { Hospitalised } \\
\text { patients (patients } \\
\text { with no severe } \\
\text { underlying } \\
\text { diseases), single } \\
\text { hospital }\end{array}$ & 95 & Univariable & N/A & $\begin{array}{l}\text { Disease } \\
\text { severity }\end{array}$ & $\begin{array}{l}\text { Severe- } \mathrm{RR} \geq 30 \text { times / } \mathrm{min} ; \text { at } \\
\text { rest, oxygen saturation } \leq 93 \% \text {; } \\
\mathrm{PaO}_{2} / \mathrm{FiO}_{2} \leq 300 \mathrm{mmHg}\end{array}$ \\
\hline $\begin{array}{l}\text { Zhang } \\
\text { (49) }\end{array}$ & $\begin{array}{l}\text { Retrospective } \\
\text { cohort }\end{array}$ & China & $\begin{array}{l}\text { Hospitalised } \\
\text { patients, single } \\
\text { hospital }\end{array}$ & 120 & Univariable & N/A & $\begin{array}{l}\text { Disease } \\
\text { severity }\end{array}$ & $\begin{array}{l}\text { Severe- when patients met one } \\
\text { of the following criteria: }(1) \\
\text { respiratory distress with a } \\
\text { breathing rate } \geq 30 / \mathrm{min} ;(2) \text { pulse } \\
\text { oximeter oxygen saturation } \leq \\
93 \% \text { at rest; }(3) \text { oxygenation } \\
\text { index }\left(\mathrm{PaO}_{2} / \mathrm{FiO}_{2}\right) \leq 300 \mathrm{mmHg} \text {; } \\
\text { (4) respiratory failure requiring } \\
\text { mechanical ventilation; (5) } \\
\text { shock; and (6) combined with } \\
\text { other organ failure requiring ICU } \\
\text { monitoring and treatment }\end{array}$ \\
\hline Zhou (50) & $\begin{array}{l}\text { Retrospective } \\
\text { cohort with a } \\
\text { nested case- } \\
\text { control study }\end{array}$ & China & $\begin{array}{l}\text { Hospitalised } \\
\text { patients across two } \\
\text { hospitals with a } \\
\text { definitive outcome }\end{array}$ & 191 & $\begin{array}{l}\text { Univariable; } \\
\text { logistic } \\
\text { regression }\end{array}$ & $\begin{array}{l}\text { N/A; age, } \\
\text { coronary heart } \\
\text { disease, } \\
\text { Sequential } \\
\text { Organ Failure } \\
\text { Assessment } \\
\text { score, } \\
\text { lymphocyte } \\
\text { count, D-dimer }\end{array}$ & Death & N/A \\
\hline
\end{tabular}

ARDS- acute respiratory distress syndrome, BMI- body mass index, CDC- Center for Disease Control and Prevention, CT- computed tomography, FiO $2-$

inspired oxygen fraction, ICNARC- intensive care national audit and research centre, ICU- intensive care unit, MERS- Middle Eastern Respiratory Syndrome,

$\mathrm{N} / \mathrm{A}$ - not applicable, $\mathrm{PaO}_{2}$ - arterial partial pressure of oxygen, $\mathrm{RR}$ - respiratory rate, $\mathrm{SARS}$ - severe acute respiratory syndrome, SpO $\mathrm{O}_{2}$ - oxygen saturation 


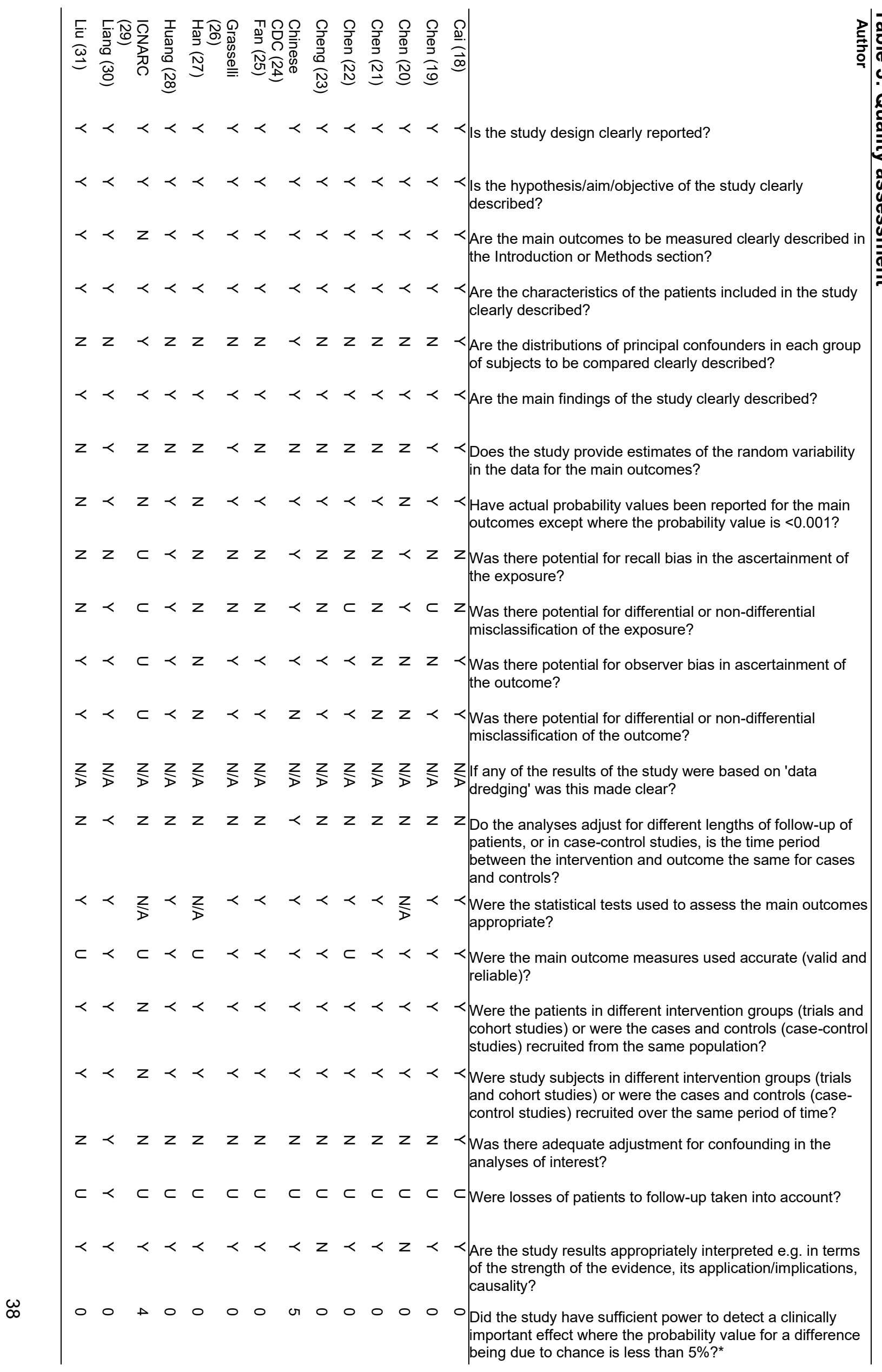




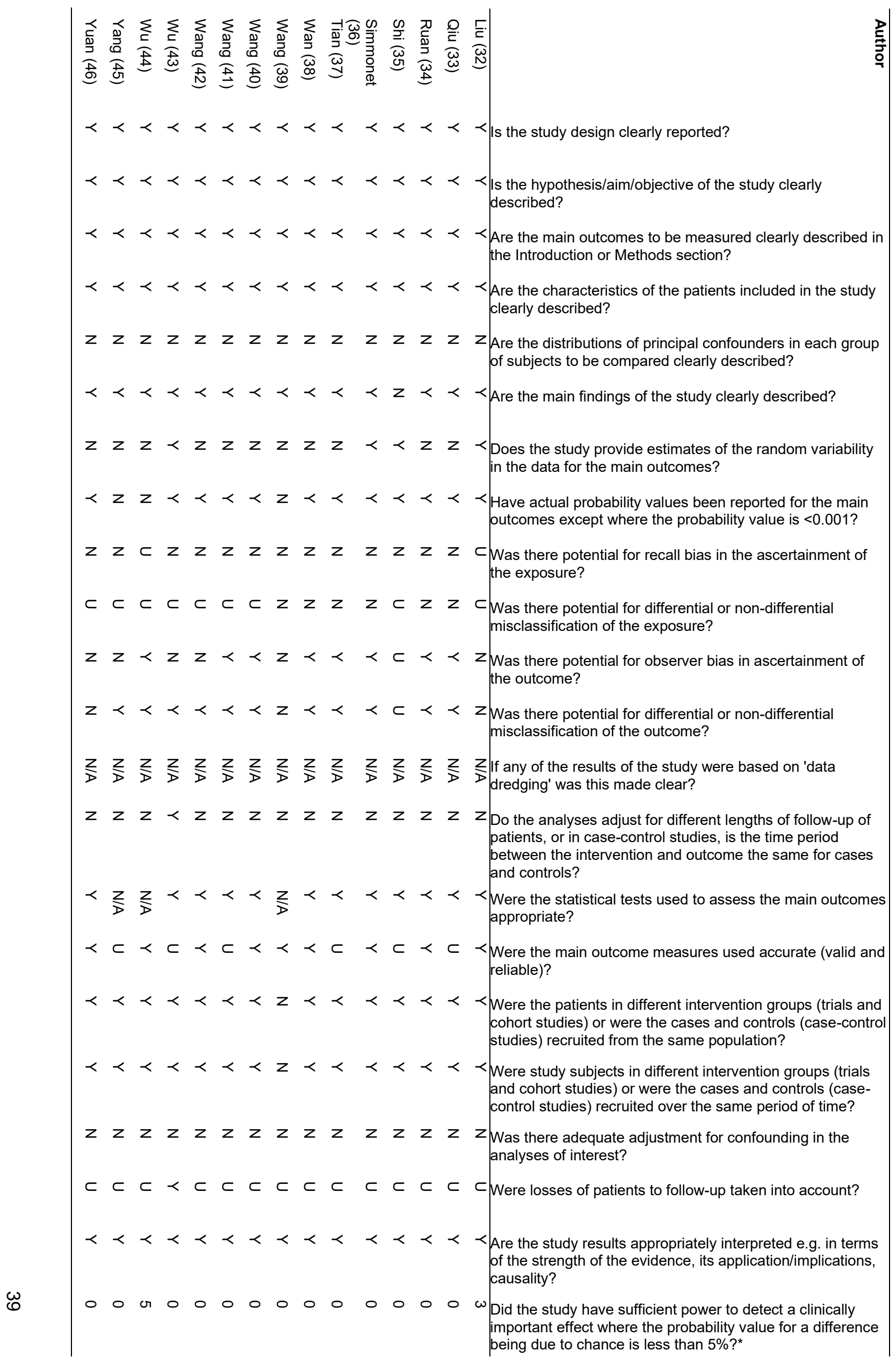




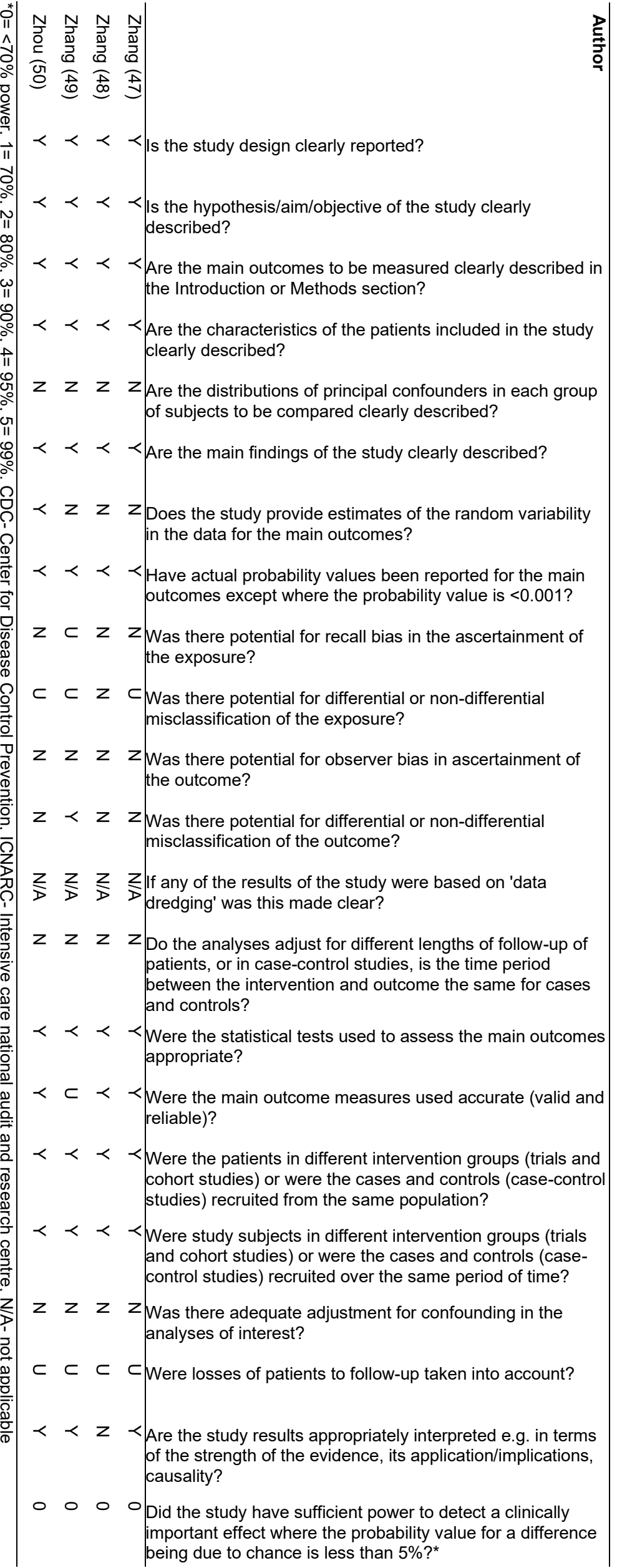


Table 4: Potential risk factors for disease

\begin{tabular}{|c|c|c|}
\hline $\begin{array}{l}\text { Potential risk } \\
\text { factor }\end{array}$ & Study supports risk & $\begin{array}{l}\text { Study does not support risk } \\
\text { or is neutral }\end{array}$ \\
\hline Age & $\begin{array}{l}\text { Patients older than those with COVID-19 and } \\
\text { younger than those with MERS } \\
\text { (descriptive)(39) } \\
\text { Younger ages (median } 45 \text { years) in patients } \\
\text { with COVID-19 than other pneumonia (median } \\
61 \text { ) (statistical test)(21) } \\
\text { Increasing risk of positivity for SARS-CoV-2 } \\
\text { among COVID-19 suspects (on the basis of } \\
\text { symptoms/contact tracing) with age (odds ratio } \\
\text { 1.02) but unclear categorisation of age } \\
\text { (multivariable regression)(32) }\end{array}$ & $\begin{array}{l}\text { Median age } 60 \text { years in those } \\
\text { with COVID-19 and } 61 \text { in those } \\
\text { with other viral pneumonia } \\
\text { (descriptive)(29) } \\
\text { Mean age } 50 \text { years in COVID- } \\
19 \text { patients vs. } 44 \text { in individuals } \\
\text { with other pneumonia (statistical } \\
\text { test)(23) }\end{array}$ \\
\hline Sex & $\begin{array}{l}\text { Sex ratio skewed towards men for COVID-19, } \\
\text { akin to MERS but not SARS (descriptive)(39) } \\
\text { Sex ratio skewed towards men for COVID-19 } \\
\text { versus other viral pneumonia (descriptive)(29) } \\
\text { Greater proportion male in COVID-19 versus } \\
\text { other pneumonia, although small sample size } \\
\text { and thus low statistical certainty (statistical } \\
\text { test)(23) } \\
\text { Increasing risk of positivity for SARS-CoV-2 } \\
\text { among COVID-19 suspects (on the basis of } \\
\text { symptoms/contact tracing) among males } \\
\text { versus female (odds ratio 1.16) (logistic } \\
\text { regression)(32) }\end{array}$ & $\begin{array}{l}\text { Sex distribution similar amongst } \\
\text { patients with COVID-19 and } \\
\text { other pneumonia (statistical } \\
\text { test)(21) }\end{array}$ \\
\hline Ethnicity & $\begin{array}{l}\text { Higher percentage of Black and Asian } \\
\text { individuals amongst COVID-19 patients than } \\
\text { patients with other viral pneumonias } \\
\text { (descriptive)(29) }\end{array}$ & \\
\hline $\begin{array}{l}\text { Index of multiple } \\
\text { deprivation }\end{array}$ & & $\begin{array}{l}\text { Distribution of deprivation } \\
\text { similar across COVID-19 and } \\
\text { other viral pneumonia } \\
\text { (descriptive)(29) }\end{array}$ \\
\hline Body mass index & $\begin{array}{l}\text { Greater proportion of COVID-19 patients had } \\
\text { higher body mass index than individuals with } \\
\text { other pneumonia (descriptive)( } 36 \text { ) } \\
\text { Greater proportion of COVID-19 patients had } \\
\text { higher body mass index than individuals with } \\
\text { other viral pneumonia (descriptive)(29) }\end{array}$ & \\
\hline Pregnancy & & $\begin{array}{l}\text { Percentage of women who were } \\
\text { pregnant similar across COVID- } \\
19 \text { and other viral pneumonia } \\
\text { (descriptive)(29) }\end{array}$ \\
\hline
\end{tabular}

MERS- middle eastern respiratory syndrome, SARS- severe acute respiratory syndrome 


\begin{tabular}{|c|c|c|}
\hline Potential risk factor & Study supports risk & $\begin{array}{l}\text { Study does not support risk } \\
\text { or is neutral }\end{array}$ \\
\hline Sex & $\begin{array}{l}\text { Odds ratio for severe disease } \\
3.68 \text { for men compared to } \\
\text { women (multivariable } \\
\text { regression)(35) } \\
\text { Odds ratio for invasive } \\
\text { mechanical ventilation } 2.83 \text { for } \\
\text { men compared to women } \\
\text { (multivariable regression)(36) } \\
\text { Females less likely to be } \\
\text { admitted to ICU, require } \\
\text { mechanical ventilation, or die; } \\
\text { odds ratio } 0.61 \text { (multivariable } \\
\text { logistic regression)(30) }\end{array}$ & $\begin{array}{l}\text { Sex distribution similar in severe } \\
\text { and non-severe disease } \\
\text { (descriptive)(29, 48) } \\
\text { Sex distribution similar in severe } \\
\text { and non-severe disease } \\
\text { (statistical test) }(22,25,27,28, \\
31,33,37,38,40-43,47-49) \\
\text { Sex distribution similar in severe } \\
\text { and non-severe disease } \\
\text { (multivariable regression)(18, } \\
19)\end{array}$ \\
\hline Age & \begin{tabular}{|l|} 
Average* 61 years severe \\
disease, 45 otherwise (statistical \\
test)(37) \\
Average* 61 years severe \\
disease, 52 years moderate \\
disease (statistical test)(22) \\
Average* 56 years severe \\
disease, 44 years mild disease \\
(statistical test)(38) \\
Median 67 years acute \\
respiratory distress syndrome, \\
52 severe, 45 mild (statistical \\
test)(41) \\
Median 64 years severe \\
patients, 52 years otherwise \\
(statistical test)(47) \\
Mean 61 years severe, \\
otherwise 40 (statistical test)(49) \\
Median 71 years SpO $2<90 \%, 37$ \\
years SpO $\geq 90 \%$ (statistical \\
test)(42) \\
Median 66 years patients in \\
ICU, 51 otherwise (statistical \\
test)(40) \\
Median 54 years patients in \\
ICU, 41 otherwise (statistical \\
test)(25) \\
65 years and over 3.26 times \\
the hazard rate of ARDS than \\
those under 65 (univariable \\
regression)(43) \\
Age associated with ICU \\
admission, odds ratio 1.06 but \\
unclear for what categorisation \\
of age (multivariable \\
regression)(19)
\end{tabular} & $\begin{array}{l}\text { Distribution of age did not differ } \\
\text { by disease severity } \\
\text { (descriptive)(29, 33, 48) } \\
\text { Distribution of age did not differ } \\
\text { by disease severity (statistical } \\
\text { test)(27, 28, 31) } \\
\text { Confidence interval for effect of } \\
\text { age (categorisation unclear) } \\
\text { crosses the null (multivariable } \\
\text { regression)(36) }\end{array}$ \\
\hline
\end{tabular}




\begin{tabular}{|c|c|c|}
\hline Potential risk factor & Study supports risk & $\begin{array}{l}\text { Study does not support risk } \\
\text { or is neutral }\end{array}$ \\
\hline Age continued & $\begin{array}{l}\text { Mean } 56 \text { years severe disease, } \\
45 \text { years mild disease; odds } \\
\text { ratio } 1.06 \text { but unclear } \\
\text { categorisation of age } \\
\text { (multivariable regression)(35) } \\
\text { Mean } 63 \text { years severe disease, } \\
41 \text { years mild disease; odds } \\
\text { ratio } 1.08 \text { but unclear } \\
\text { categorisation of age } \\
\text { (multivariable regression)(18) } \\
\text { Older individuals more likely to } \\
\text { be admitted to ICU, require } \\
\text { mechanical ventilation, or die; } \\
\text { odds ratio } 1.05, \text { categories of } \\
\text { age unclear (multivariable } \\
\text { logistic regression)(30) }\end{array}$ & \\
\hline Ethnicity & $\begin{array}{l}76.3 \% \text { of individuals receiving } \\
\text { basic respiratory support were } \\
\text { White versus } 65.6 \% \text { receiving } \\
\text { advanced respiratory support; } \\
\text { Asian and Black ethnicities } \\
\text { appear most at risk of severe } \\
\text { disease (England, Northern } \\
\text { Ireland and Wales; } \\
\text { descriptive)(29) }\end{array}$ & $\begin{array}{l}\text { Distribution of disease severity } \\
\text { similar across ethnic groups } \\
\text { (Chinese, Malay, Indian, other - } \\
\text { with small numbers in groups } \\
\text { other than Chinese; study in } \\
\text { Singapore; descriptive)(25) }\end{array}$ \\
\hline Deprivation & & $\begin{array}{l}\text { Distribution across deprivation } \\
\text { categories similar } \\
\text { (descriptive)(29) }\end{array}$ \\
\hline Pregnancy & & $\begin{array}{l}\text { Distribution in pregnant and } \\
\text { non-pregnant individuals similar } \\
\text { across disease severity } \\
\text { (descriptive)(29) }\end{array}$ \\
\hline Smoking & $\begin{array}{l}100 \% \text { of current smokers had } \\
\text { severe disease, but only six } \\
\text { individuals smoked(49) }\end{array}$ & $\begin{array}{l}\text { Distribution in current and non- } \\
\text { current smokers similar across } \\
\text { disease severity (descriptive), } \\
\text { only three individuals } \\
\text { smoked(38) } \\
\text { Distribution in current and non- } \\
\text { current smokers similar across } \\
\text { disease severity (statistical test); } \\
\text { small numbers who smoked } \\
(28) \\
\text { Distribution in historical/current } \\
\text { and non-smokers similar across } \\
\text { disease severity (statistical } \\
\text { test)(35, 47) }\end{array}$ \\
\hline Body mass index & $\begin{array}{l}\geq 35 \mathrm{~kg} / \mathrm{m}^{2} \text { risk factor versus } \\
<25 \mathrm{~kg} / \mathrm{m}^{2} \text { for invasive } \\
\text { mechanical ventilation; odds } \\
\text { ratio } 7.36 \text {. Results for other } \\
\text { strata cross the null } \\
\text { (multivariable regression)(36) } \\
\text { Increasing body mass index } \\
\text { increased risk; odds ratio } 1.17 \\
\text { (categorisation unclear)(18) }\end{array}$ & $\begin{array}{l}\text { Distribution of disease severity } \\
\text { similar across body mass index } \\
\text { categories (descriptive)(29) }\end{array}$ \\
\hline
\end{tabular}




\begin{tabular}{|c|c|c|}
\hline Potential risk factor & Study supports risk & $\begin{array}{l}\text { Study does not support risk } \\
\text { or is neutral }\end{array}$ \\
\hline Any/other comorbidity & $\begin{array}{l}\text { Presence of comorbidity more } \\
\text { common among those with } \\
\text { severe disease (statistical } \\
\text { test) }(38,40,47,49)\end{array}$ & $\begin{array}{l}\text { Distribution with and without } \\
\text { condition similar across disease } \\
\text { severity (statistical test) }(22,28, \\
35) \\
\text { Distribution with and without } \\
\text { comorbidities not otherwise } \\
\text { considered in the study similar } \\
\text { across disease severity } \\
\text { (statistical test)(49) } \\
\text { Distribution with and without } \\
\text { condition similar across disease } \\
\text { severity (multivariable } \\
\text { regression)(19) }\end{array}$ \\
\hline $\begin{array}{l}\text { Cardiovascular disease/chronic } \\
\text { heart disease/coronary heart } \\
\text { disease }\end{array}$ & $\begin{array}{l}\text { Presence of comorbidity more } \\
\text { common among those with } \\
\text { severe disease (descriptive)(38) } \\
\text { Presence of comorbidity more } \\
\text { common among those with } \\
\text { severe disease (statistical } \\
\text { test) }(18,35,40,42,49)\end{array}$ & $\begin{array}{l}\text { Distribution with and without } \\
\text { condition similar across disease } \\
\text { severity (descriptive) }(29,43) \\
\text { Distribution with and without } \\
\text { condition similar across disease } \\
\text { severity (statistical test) }(28,47)\end{array}$ \\
\hline Hypertension & $\begin{array}{l}\text { Presence of comorbidity more } \\
\text { common among those with } \\
\text { severe disease (statistical } \\
\text { test)(40, 42, 49) } \\
\text { Hazard ratio of ARDS } 1.82 \text { in } \\
\text { those with the condition versus } \\
\text { those without (univariable } \\
\text { regression)(43) } \\
\text { Odds ratio of severe disease } \\
2.71 \text { in those with the condition } \\
\text { versus those without } \\
\text { (multivariable regression)(35) } \\
\text { Odds ratio of being admitted to } \\
\text { ICU, require mechanical } \\
\text { ventilation, or die } 1.89 \text { in those } \\
\text { with the condition versus those } \\
\text { without (multivariable } \\
\text { regression)(30) }\end{array}$ & $\begin{array}{l}\text { Distribution with and without } \\
\text { condition similar across disease } \\
\text { severity (descriptive)(38) } \\
\text { Distribution with and without } \\
\text { condition similar across disease } \\
\text { severity (statistical test); one } \\
\text { study with small numbers with } \\
\text { the condition(22, } 28,41,47) \\
\text { Confidence interval in presence } \\
\text { and absence of condition } \\
\text { crosses the null (multivariable } \\
\text { regression)(18) } \\
\text { Confidence interval in presence } \\
\text { and absence of condition } \\
\text { crosses the null (multivariable } \\
\text { regression, result } \\
\text { borderline)(36) }\end{array}$ \\
\hline Diabetes & $\begin{array}{l}\text { Presence of comorbidity more } \\
\text { common among those with } \\
\text { severe disease (descriptive)(38) } \\
\text { Presence of comorbidity more } \\
\text { common among those with } \\
\text { severe disease (statistical } \\
\text { test) }(18,35,40,42,49) \\
\text { Hazard ratio of ARDS } 2.34 \text { in } \\
\text { those with the condition versus } \\
\text { those without (univariable } \\
\text { regression)(43) } \\
\text { Odds ratio of being admitted to } \\
\text { ICU, require mechanical } \\
\text { ventilation, or die } 2.21 \text { in those } \\
\text { with the condition versus those } \\
\text { without (multivariable } \\
\text { regression)(30) }\end{array}$ & $\begin{array}{l}\text { Distribution with and without } \\
\text { condition similar across disease } \\
\text { severity (statistical test); small } \\
\text { numbers with condition(22) } \\
\text { Distribution with and without } \\
\text { condition similar across disease } \\
\text { severity (statistical test) }(28,47) \\
\text { Distribution with and without } \\
\text { condition similar across disease } \\
\text { severity (statistical test, } \\
\text { borderline result)(41) } \\
\text { Confidence interval in presence } \\
\text { and absence of condition } \\
\text { crosses the null (multivariable } \\
\text { regression)(36) }\end{array}$ \\
\hline Respiratory/pulmonary disease & & $\begin{array}{l}\text { Distribution with and without } \\
\text { condition similar across disease } \\
\text { severity (descriptive })(29,38)\end{array}$ \\
\hline
\end{tabular}




\begin{tabular}{|c|c|c|}
\hline Potential risk factor & Study supports risk & $\begin{array}{l}\text { Study does not support risk } \\
\text { or is neutral }\end{array}$ \\
\hline Asthma & & $\begin{array}{l}\text { Distribution with and without } \\
\text { condition similar across disease } \\
\text { severity (statistical test); small } \\
\text { numbers with condition (42) }\end{array}$ \\
\hline $\begin{array}{l}\text { Chronic obstructive pulmonary } \\
\text { disease (COPD) }\end{array}$ & $\begin{array}{l}\text { Presence of comorbidity more } \\
\text { common among those with } \\
\text { severe disease (descriptive); } \\
\text { small numbers with } \\
\text { condition(38) } \\
\text { Presence of comorbidity more } \\
\text { common among those with } \\
\text { severe disease (statistical test); } \\
\text { both studies have small } \\
\text { numbers with the condition(40, } \\
49 \text { ) } \\
\text { Odds ratio of being admitted to } \\
\text { ICU, require mechanical } \\
\text { ventilation, or die } 3.40 \text { in those } \\
\text { with the condition versus those } \\
\text { without (multivariable } \\
\text { regression)(30) }\end{array}$ & $\begin{array}{l}\text { Distribution with and without } \\
\text { condition similar across disease } \\
\text { severity (statistical test); small } \\
\text { numbers with condition( } 28,42, \\
47 \text { ) }\end{array}$ \\
\hline Pulmonary tuberculosis & & $\begin{array}{l}\text { Distribution with and without } \\
\text { condition similar across disease } \\
\text { severity (statistical test); small } \\
\text { numbers with condition (47) }\end{array}$ \\
\hline Malignancy & $\begin{array}{l}\text { Presence of comorbidity more } \\
\text { common among those with } \\
\text { severe disease (statistical test); } \\
\text { small numbers with } \\
\text { condition(38) } \\
\text { Presence of comorbidity more } \\
\text { common among those with } \\
\text { severe disease (statistical } \\
\text { test)(35, } 41,49) \\
\text { Presence of comorbidity more } \\
\text { common among those with } \\
\text { severe disease (multivariable } \\
\text { analysis)(30) }\end{array}$ & $\begin{array}{l}\text { Distribution with and without } \\
\text { condition similar across disease } \\
\text { severity (descriptive)(29) } \\
\text { Distribution with and without } \\
\text { condition similar across disease } \\
\text { severity (statistical test)(40) } \\
\text { Distribution with and without } \\
\text { condition similar across disease } \\
\text { severity (statistical test); small } \\
\text { numbers with condition (18, 28, } \\
42)\end{array}$ \\
\hline Cerebrovascular disease & $\begin{array}{l}\text { Presence of comorbidity more } \\
\text { common among those with } \\
\text { severe disease (statistical } \\
\text { test)(40) }\end{array}$ & \\
\hline Arrhythmia & & $\begin{array}{l}\text { Distribution with and without } \\
\text { condition similar across disease } \\
\text { severity (statistical test); small } \\
\text { numbers with the condition(47) }\end{array}$ \\
\hline Cerebral infarction & & $\begin{array}{l}\text { Distribution with and without } \\
\text { condition similar across disease } \\
\text { severity (statistical test)(41) }\end{array}$ \\
\hline Stroke & & $\begin{array}{l}\text { Distribution with and without } \\
\text { condition similar across disease } \\
\text { severity (statistical test); small } \\
\text { numbers with condition(47) } \\
\end{array}$ \\
\hline Aorta sclerosis & & $\begin{array}{l}\text { Distribution with and without } \\
\text { condition similar across disease } \\
\text { severity (statistical test); small } \\
\text { numbers with condition(47) }\end{array}$ \\
\hline
\end{tabular}




\begin{tabular}{|c|c|c|}
\hline Potential risk factor & Study supports risk & $\begin{array}{l}\text { Study does not support risk } \\
\text { or is neutral }\end{array}$ \\
\hline $\begin{array}{l}\text { Chronic kidney disease/renal } \\
\text { issues }\end{array}$ & $\begin{array}{l}\text { Presence of comorbidity more } \\
\text { common among those with } \\
\text { severe disease (statistical } \\
\text { test)(41) }\end{array}$ & $\begin{array}{l}\text { Distribution with and without } \\
\text { condition similar across disease } \\
\text { severity (descriptive)(29) } \\
\text { Distribution with and without } \\
\text { condition similar across disease } \\
\text { severity (statistical test); small } \\
\text { numbers with the condition(40) }\end{array}$ \\
\hline Chronic renal disease/insufficiency & & $\begin{array}{l}\text { Distribution with and without } \\
\text { condition similar across disease } \\
\text { severity (statistical test); one } \\
\text { study has small numbers of } \\
\text { patients with the condition( } 35 \text {, } \\
\text { 47) }\end{array}$ \\
\hline Chronic liver disease & & $\begin{array}{l}\text { Distribution with and without } \\
\text { condition similar across disease } \\
\text { severity (descriptive), } \\
\text { sometimes small numbers with } \\
\text { condition }(18,29,38) \\
\text { Distribution with and without } \\
\text { condition similar across disease } \\
\text { severity (statistical test)(35, } 40) \\
\text { Distribution with and without } \\
\text { condition similar across disease } \\
\text { severity (statistical test); small } \\
\text { numbers with condition }(28,49)\end{array}$ \\
\hline $\begin{array}{l}\text { Fatty liver and abnormal liver } \\
\text { function }\end{array}$ & & $\begin{array}{l}\text { Distribution with and without } \\
\text { condition similar across disease } \\
\text { severity (statistical test)(47) }\end{array}$ \\
\hline Hyperlipidaemia & & $\begin{array}{l}\text { Distribution with and without } \\
\text { condition similar across disease } \\
\text { severity (statistical test)(47) }\end{array}$ \\
\hline Dyslipidemia & & $\begin{array}{l}\text { Confidence interval in presence } \\
\text { and absence of condition } \\
\text { crosses the null (multivariable } \\
\text { regression)(36) }\end{array}$ \\
\hline Chronic gastritis/gastric ulcer & & $\begin{array}{l}\text { Distribution with and without } \\
\text { condition similar across disease } \\
\text { severity (statistical test)(47) }\end{array}$ \\
\hline Cholelithiasis & & $\begin{array}{l}\text { Distribution with and without } \\
\text { condition similar across disease } \\
\text { severity (statistical test)(47) }\end{array}$ \\
\hline Urolithiasis & & $\begin{array}{l}\text { Distribution with and without } \\
\text { condition similar across disease } \\
\text { severity (statistical test); small } \\
\text { numbers with condition(47) }\end{array}$ \\
\hline Thyroid diseases & & $\begin{array}{l}\text { Distribution with and without } \\
\text { condition similar across disease } \\
\text { severity (statistical test); small } \\
\text { numbers with the condition(47) }\end{array}$ \\
\hline Electrolyte imbalance & $\begin{array}{l}\text { Presence of comorbidity more } \\
\text { common among those with } \\
\text { severe disease (statistical test); } \\
\text { small numbers with } \\
\text { condition(47) }\end{array}$ & \\
\hline Agglomerative disease & & $\begin{array}{l}\text { Distribution with and without } \\
\text { condition similar across disease } \\
\text { severity (descriptive); small } \\
\text { numbers with the condition(38) }\end{array}$ \\
\hline
\end{tabular}




\begin{tabular}{l|l|l}
\hline Potential risk factor & Study supports risk & $\begin{array}{l}\text { Study does not support risk } \\
\text { or is neutral }\end{array}$ \\
\hline Immunocompromised & $\begin{array}{l}\text { Distribution with and without } \\
\text { condition similar across disease } \\
\text { severity (descriptive)(29) }\end{array}$ \\
\hline Chronic hepatitis & $\begin{array}{l}\text { Distribution with and without } \\
\text { condition similar across disease } \\
\text { severity (statistical test); small } \\
\text { numbers with condition(42) }\end{array}$ \\
\hline HIV & $\begin{array}{l}\text { Distribution with and without } \\
\text { condition similar across disease } \\
\text { severity (statistical test); small } \\
\text { numbers with condition(40) }\end{array}$ \\
\hline Living without assistance & $\begin{array}{l}\text { Distribution with and without } \\
\text { condition similar across disease } \\
\text { severity (descriptive)(29) }\end{array}$ \\
\hline
\end{tabular}

One study included death in a combined measure of disease severity.(30) *Unclear as to whether mean, median or mode. ARDS- acute respiratory distress syndrome, ICU- intensive care unit, $\mathrm{SpO}_{2}$ - oxygen saturation 
Table 6: Potential risk factors for mortality

\begin{tabular}{|c|c|c|}
\hline Potential risk factor & Study supports risk & $\begin{array}{l}\text { Study does not support risk } \\
\text { or is neutral }\end{array}$ \\
\hline Sex & $\begin{array}{l}\text { Men more at risk } \\
\text { (descriptive)(20) }\end{array}$ & $\begin{array}{l}\text { Sex distribution similar amongst } \\
\text { patients who died and survived } \\
\text { (descriptive)(24, } 34,45,46) \\
\text { Confidence interval for males } \\
\text { versus females crosses the null } \\
\text { (univariable regression)(43) }\end{array}$ \\
\hline Age & $\begin{array}{l}\text { Over } 60 \text { years particular at risk } \\
\text { (descriptive)(20) } \\
8 \% \text { case fatality ratio in } 70-79 \\
\text { year olds and } 14.8 \% \text { in those } \\
\text { over } 80 . \text { Overall figure } 2.3 \% \\
\text { (descriptive)(44) } \\
\text { Median age in those who died } \\
52 \text { years, } 65 \text { years among } \\
\text { survivors (descriptive)(45) } \\
\text { Over } 50 \text { years of age } \\
\text { particularly at risk- } 1.3 \% \text { died } \\
50-59 \text { years, } 3.6 \% 60-69 \text { years, } \\
8.0 \% 70-79 \text { years, } 14.8 \% 80 \\
\text { years plus; less than } 1 \% \text { all } \\
\text { other age groups } \\
\text { (descriptive)(24) } \\
\text { Risk begins to increase at } \\
\text { approximately } 50 \text { years } \\
\text { (statistical test, but graphical } \\
\text { presentation)(34) } \\
\text { Median age in those who died } \\
68 \text { years, among those who } \\
\text { survived } 55 \text { (statistical test)(46) } \\
\text { Over } 61 \text { years, increasing per } \\
10 \text { year age group (statistical } \\
\text { test)(26) } \\
65 \text { years and older } 6.17 \text { the } \\
\text { hazard rate of those under } 65 \\
\text { (univariable regression)(43) }\end{array}$ & \\
\hline Smoking & & $\begin{array}{l}\text { Proportion of smokers similar } \\
\text { among those who died versus } \\
\text { those who did not (descriptive) } \\
\text { one study had small numbers of } \\
\text { smokers (20, 45) } \\
\text { Distribution of current smokers } \\
\text { similar among survivors and } \\
\text { non-survivors (univariable } \\
\text { regression analysis, not } \\
\text { included in multivariable } \\
\text { model)(50) }\end{array}$ \\
\hline Pregnancy & & $\begin{array}{l}\text { Proportion of women who were } \\
\text { pregnant similar amongst } \\
\text { patients who died versus } \\
\text { survived (descriptive)(20) }\end{array}$ \\
\hline Any comorbidity & $\begin{array}{l}\text { Presence of any comorbidity } \\
\text { more common among those } \\
\text { dying (descriptive)(20,34, } 45 \text {, } \\
46,50)\end{array}$ & \\
\hline
\end{tabular}




\begin{tabular}{|c|c|c|}
\hline Potential risk factor & Study supports risk & $\begin{array}{l}\text { Study does not support risk } \\
\text { or is neutral }\end{array}$ \\
\hline Hypertension & $\begin{array}{l}\text { Presence of condition more } \\
\text { common among those dying } \\
\text { (descriptive)(3,20, 24, 26) } \\
\text { Presence of condition more } \\
\text { common among those dying } \\
\text { (statistical test) }(46,50)\end{array}$ & $\begin{array}{l}\text { Confidence interval for } \\
\text { individuals with and without the } \\
\text { condition crosses the null } \\
\text { (univariable regression)(43) }\end{array}$ \\
\hline $\begin{array}{l}\text { Cardiovascular disease/chronic } \\
\text { heart disease }\end{array}$ & $\begin{array}{l}\text { Presence of condition more } \\
\text { common among those dying } \\
\text { (descriptive) }(20,24,34,44) \\
\text { Presence of condition more } \\
\text { common among those dying } \\
\text { (statistical test) }(46,50)\end{array}$ & $\begin{array}{l}\text { Distribution dying in presence } \\
\text { and absence of comorbidity } \\
\text { similar (descriptive), sometimes } \\
\text { small numbers with the } \\
\text { condition }(43,45)\end{array}$ \\
\hline Diabetes & $\begin{array}{l}\text { Presence of condition more } \\
\text { common among those dying } \\
\text { (descriptive) }(20,24,44,45) \\
\text { Presence of condition more } \\
\text { common among those dying } \\
\text { (statistical test) }(46,50)\end{array}$ & $\begin{array}{l}\text { Confidence interval for } \\
\text { individuals with and without the } \\
\text { condition crosses the null } \\
\text { (univariable regression)(43) }\end{array}$ \\
\hline $\begin{array}{l}\text { Chronic respiratory/lung disease } \\
\text { (chronic obstructive lung disease) }\end{array}$ & $\begin{array}{l}\text { Presence of condition more } \\
\text { common among those dying } \\
\text { (descriptive)(20,44) } \\
\text { Presence of condition more } \\
\text { common among those dying } \\
\text { (statistical test)(50) }\end{array}$ & $\begin{array}{l}\text { Distribution dying in presence } \\
\text { and absence of comorbidity } \\
\text { similar (descriptive)(45) }\end{array}$ \\
\hline Respiratory infectious disease & $\begin{array}{l}\text { Presence of condition more } \\
\text { common among those dying } \\
\text { (descriptive)(24) }\end{array}$ & \\
\hline Malignancy & $\begin{array}{l}\text { Presence of condition more } \\
\text { common among those dying } \\
\text { (descriptive)(3, 24) }\end{array}$ & $\begin{array}{l}\text { Distribution dying in presence } \\
\text { and absence of comorbidity } \\
\text { similar (descriptive), sometimes } \\
\text { small numbers with the } \\
\text { condition }(45,46,50)\end{array}$ \\
\hline $\begin{array}{l}\text { Cerebral infarction/ } \\
\text { cerebrovascular disease }\end{array}$ & $\begin{array}{l}\text { Presence of condition more } \\
\text { common among those dying } \\
\text { (descriptive)(45) }\end{array}$ & $\begin{array}{l}\text { Distribution dying in presence } \\
\text { and absence of comorbidity } \\
\text { similar (statistical test); small } \\
\text { numbers with the condition(46) }\end{array}$ \\
\hline Chronic gastritis & & $\begin{array}{l}\text { Distribution dying in presence } \\
\text { and absence of comorbidity } \\
\text { similar (statistical test); small } \\
\text { numbers with the condition(46) }\end{array}$ \\
\hline Chronic kidney disease & $\begin{array}{l}\text { Presence of condition more } \\
\text { common among those dying } \\
\text { (statistical test); small numbers } \\
\text { with the condition (50) }\end{array}$ & \\
\hline Dementia & & $\begin{array}{l}\text { Distribution dying in presence } \\
\text { and absence of comorbidity } \\
\text { similar (descriptive); small } \\
\text { numbers with the condition(45) }\end{array}$ \\
\hline Malnutrition & & $\begin{array}{l}\text { Distribution dying in presence } \\
\text { and absence of comorbidity } \\
\text { similar (descriptive); small } \\
\text { numbers with the condition(45) }\end{array}$ \\
\hline Hepatitis B virus infection & & $\begin{array}{l}\text { Distribution dying in presence } \\
\text { and absence of comorbidity } \\
\text { similar (descriptive)(20) }\end{array}$ \\
\hline
\end{tabular}




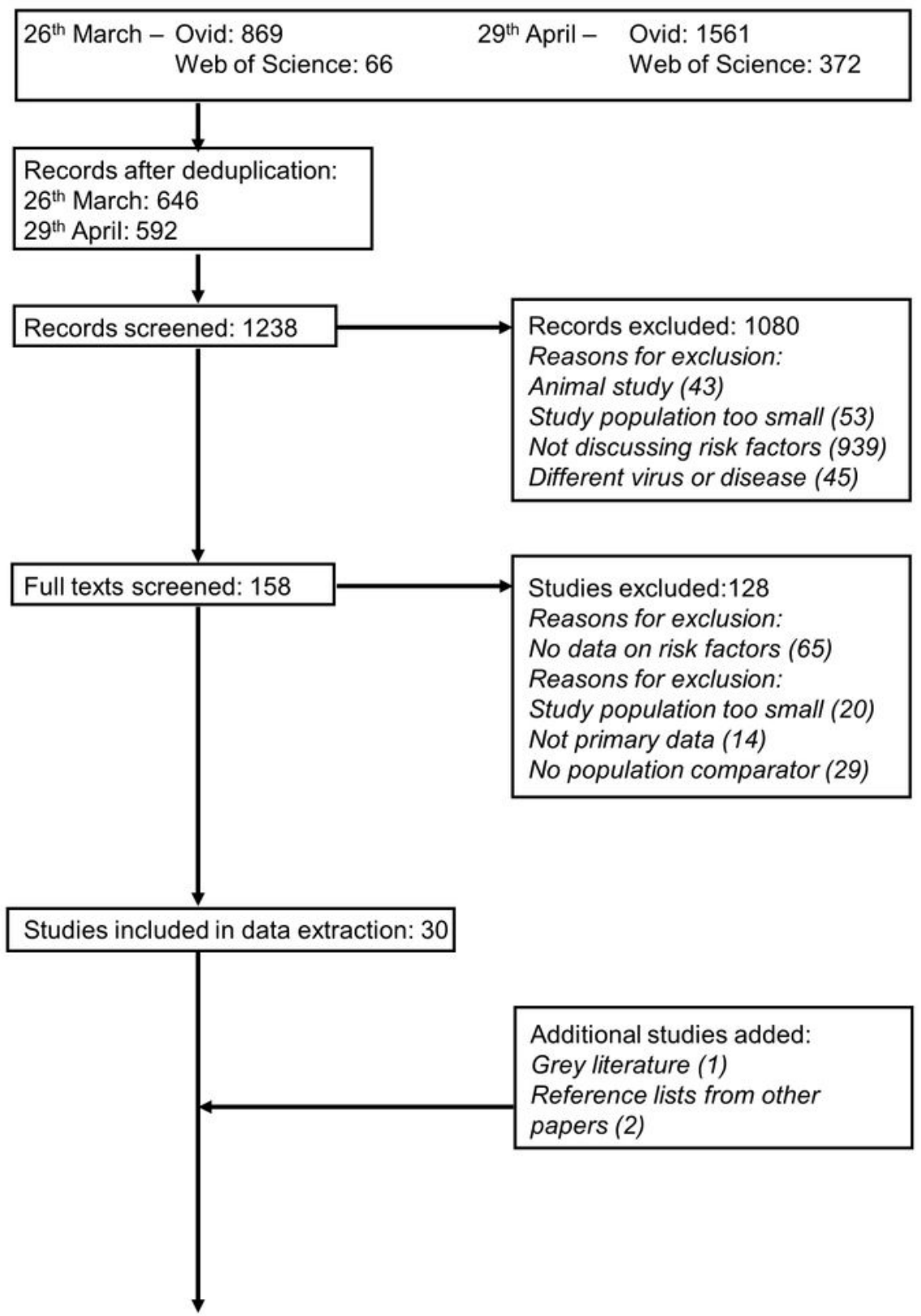

Included in data synthesis: 33

Figure 1

PRISMA flow chart of selection 
This is a list of supplementary files associated with this preprint. Click to download.

- Tables.docx 